\title{
HOMOPLASIOUS CHARACTER COMBINATIONS AND GENERIC DElimitation: A CASE STUDY FROM THE INDO-PACIFIC arecoid palms (Arecaceae: Areceae) ${ }^{1}$
}

\author{
Maria Vibe Norup, ${ }^{2,3,5}$ John Dransfield, ${ }^{3}$ Mark W. Chase, ${ }^{3}$ Anders S. Barfod, ${ }^{2}$ \\ Edwino S. Fernando, ${ }^{4}$ And William J. BaKer ${ }^{3}$ \\ ${ }^{2}$ Department of Systematic Botany, University of Aarhus, Ny Munkegade, Building 540, 8000 Aarhus, Denmark; ${ }^{3}$ Royal Botanic \\ Gardens, Kew, Richmond, Surrey, TW9 3AB, UK; and ${ }^{4}$ Department of Forest Biological Sciences, The University of the \\ Philippines, Los Baños, College, 4031 Laguna, Philippines
}

\begin{abstract}
The complex distributions of morphological character states in the Indo-Pacific palm tribe Areceae (Arecaceae; Arecoideae) are potentially challenging for the delimitation of its genera. In the first exhaustive sampling of all 65 genera of the Areceae, we examined relationships of two of the tribe's most problematic genera, Heterospathe and Rhopaloblaste, using portions of the lowcopy nuclear genes phosphoribulokinase $(P R K)$ and RNA-polymerase II subunit B (RPB2). Both genera fell within a highly supported clade comprising all Areceae genera, but are clearly unrelated. Rhopaloblaste was strongly supported as monophyletic and is most closely related to Indian Ocean genera. Heterospathe was resolved with strong support within a clade of western Pacific genera, but with the monotypic Alsmithia nested within it. Ptychosperma micranthum, which has previously been included in both Heterospathe and Rhopaloblaste, is excluded from these and from Ptychosperma, supporting its recent placement in a new genus Dransfieldia. Morphological comparisons indicate that the crownshaft is putatively synapomorphic for the Areceae with numerous reversals within the clade and some independent origins elsewhere. The putative diagnostic characters of Heterospathe show high levels of homoplasy, and the genus can only be distinguished by a suite of characters, whereas Rhopaloblaste is more clearly defined. Our results have implications not only for the two genera in focus, but have also been influential for the new classification of the Areceae.
\end{abstract}

Key words: Arecaceae; biogeography; Heterospathe; low-copy nuclear DNA; molecular phylogenetics; morphology; pseudomonomery; Rhopaloblaste.

Extremely high levels of morphological homoplasy in large and species-rich plant groups (e.g., Baker et al., 2000a; Moylan et al., 2004; Tam et al., 2004) are frequently responsible for problems in generic delimitation. Furthermore, while genus circumscriptions may be strongly supported by evidence from DNA sequence data, unique morphological synapomorphies may be lacking, the group being defined on combinations of homoplasious character states (e.g., Hughes et al., 2004). Within the palm family, generic limits are especially challenging in tribe Areceae (Arecoideae), a species-rich group comprising more than 660 species in 65 genera in the latest classification of palms (Dransfield et al., 2005; Govaerts and Dransfield, 2005). However, a detailed and well-resolved phylogenetic study of the group with which generic limits may be tested is not yet available.

The Areceae is an Old World tribe distributed throughout the Indo-Pacific region from Pemba in the west to Samoa in the

\footnotetext{
${ }^{1}$ Manuscript received 21 May 2005; revision accepted 27 April 2006.

The authors thank V. Savolainen, A. Loo, C. Lewis, and J. Roncal for sharing unpublished sequences for this paper, D. Springate, O. Maurin, and T. Wilmot for helping with sequence generation, the staff at the Jodrell Laboratory, RBG Kew, for technical assistance, C. Lewis, C. Asmussen, J.-C. Pintaud, R. Banka, R. Maturbongs, J. Wanggai, C. Heatubun, A. Loo, P. Forster, and S. Zona for supplying DNA samples, and C. Asmussen and two anonymous reviewers for providing constructive comments on earlier versions of the manuscript. M. V. N. was able to conduct her studies at the Royal Botanic Gardens, Kew, thanks to support from the Oticon Foundation, the Faculty of Science, University of Aarhus, and the Royal Botanic Gardens, Kew. DNA sequencing was in part funded by grants from the Royal Society, the Leverhulme Trust, and the British American Tobacco Biodiversity Partnership.

${ }^{5}$ Author for correspondence (e-mail: mnorup@snm.ku.dk)
}

east, with centers of diversity in Madagascar, the Sunda Shelf, Papuasia, and the western Pacific region (Dransfield et al., 2005; Govaerts and Dransfield, 2005). The great diversification of Areceae in the area is paralleled by other higher plants and has most likely been spurred on by the complex geological and climatic history of the region and the many niches presented by the numerous islands and archipelagos of the Indo-Pacific region (Turner, 1995; Ridder-Numan, 1996; Dransfield, 1999; Morley, 2000, 2001). Most members of the tribe are mediumsized to large, monoecious palms characterized by reduplicately pinnate leaves and a crownshaft (a conspicuous cylinder of tubular, neatly abscising leaf sheaths at the stem tip). Inflorescences in bud are usually enclosed within a prophyll and typically one conspicuous peduncular bract. In the pistillate flower, the gynoecium comprises one fertile carpel with a single ovule and remnants of two aborted carpels and is thus termed pseudomonomerous.

The delimitation of the Areceae has recently been revised in the new phylogenetic classification of palms that is followed here (Dransfield et al., 2005). Two recent molecular phylogenetic studies focusing on relationships within Arecoideae have indicated that the Areceae as defined in the previous classification (Uhl and Dransfield, 1987; Dransfield and Uhl, 1998) is not monophyletic (Hahn, 2002; Lewis and Doyle, 2002). These authors also identified a strongly supported clade of Indo-Pacific, pseudomonomerous genera that now equates to tribe Areceae sensu Dransfield et al. (2005). This clade was also recovered in family-wide phylogenetic studies, although without bootstrap support greater than 50\% (Baker et al., 1999; Asmussen et al., 2000; Asmussen and Chase, 2001; Asmussen et al., in press). The majority of genera of Areceae sensu Uhl 
and Dransfield (1987) are included within the limits of the revised concept of the tribe, the remainder being placed in other tribes such as Euterpeae, Oranieae, and Roystoneae. Surprisingly, two Pacific genera, Pelagodoxa Becc. and Sommieria Becc., which conform to the Areceae both in their biogeography and in their pseudomonomerous gynoecia (Stauffer et al., 2004), are also excluded from the Areceae according to the analysis of Lewis and Doyle (2002) and have consequently been placed in their own tribe Pelagodoxeae (Dransfield et al., 2005).

Generally, the Areceae is characterized by a complex yet limited range of morphological diversity with genera distinguished on combinations of widespread character states. This situation is highly problematic for identification and delimitation of genera. The current paper focuses on two such genera within the Areceae (Lewis and Doyle, 2002), Heterospathe Scheff. and Rhopaloblaste Scheff. (Areceae, subtribe Iguanurinae; Uhl and Dransfield, 1987), the circumscription of which has caused considerable confusion in the past. Heterospathe contains 38 species with a center of species diversity in New Guinea that extends into the western Pacific, particularly the Solomon Islands, the Philippines, and the Moluccas (Govaerts and Dransfield, 2005). The six species of Rhopaloblaste are disjunctly distributed across Wallace's Line with one species in the Nicobar Islands, one in Peninsular Malaysia and Singapore, and the remaining four species from the Moluccas to New Guinea and the Solomons (Banka and Baker, 2004). Like many other Areceae, Heterospathe and Rhopaloblaste appear to be defined by potentially homoplasious characters. For example, inflorescence morphology of Heterospathe is highly reminiscent of that in Alsmithia H. E. Moore, and there are numerous examples of other Areceae that, like Heterospathe, do not possess a crownshaft (e.g., Lepidorrhachis (H. Wendl \& Drude) O.F. Cook and Cyphosperma H. Wendl.). A recent revision of Rhopaloblaste (Banka and Baker, 2004) has to some extent clarified the diagnostic characters of this genus, although the uniqueness of any of these features has not been established. For example, several other palm genera, such as Cyrtostachys Blume, display the strongly recurving primary inflorescence branches that are said to be distinctive in Rhopaloblaste.

Heterospathe and Rhopaloblaste are currently accepted as distinct genera, but their taxonomic histories are intertwined with several other genera, a common situation throughout the Areceae. The two genera were originally described by Scheffer (1876) in the same publication. Today, a number of species currently accepted in Heterospathe were originally described in Rhopaloblaste (e.g., R. macgregorii Becc., transferred to H. macgregorii (Becc.) H. E. Moore; Moore, 1970). In addition, several species currently placed in both Heterospathe and Rhopaloblaste were originally described in another genus, Ptychoraphis Becc. (Beccari, 1885). Ptychoraphis, however, is problematic because the distinguishing characters are reminiscent of characters used to define Heterospathe and Rhopaloblaste (Moore, 1970). Beccari himself later transferred members of Ptychoraphis to both Heterospathe (Beccari, 1909) and Rhopaloblaste (Beccari ex Martelli, 1934, 1935). In his revision of Rhopaloblaste, Moore (1970) finally sank Ptychoraphis and split the remaining species between Heterospathe and Rhopaloblaste. One species remains strikingly problematic. Originally described as Ptychosperma micranthum Becc., it combines the features of several genera of Areceae, and its taxonomic position has been disputed ever since it was described by Beccari (1877). Hooker (1883) referred it to Rhopaloblaste (although the combination was not validly published until Jackson (1895), but Moore (1970) later decided to include the species in Heterospathe. The species does not conform to the modern delimitation of any of the three genera to which it has been ascribed and its correct placement remains unclear.

The tortuous taxonomic history and the lack of clear diagnostic features described above call into question the monophyly of Heterospathe and Rhopaloblaste. Furthermore, a clarification of generic limits is required for on-going taxonomic work in Papuasia, the center of diversity for both genera (Baker, 2002). In a biogeographical context, Heterospathe and Rhopaloblaste are particularly significant because they both have wide distributions. Rhopaloblaste is in fact one of the few palm genera to occur on islands in both the Indian and Pacific Oceans. To assess the monophyly of Heterospathe and Rhopaloblaste and establish their relationships and the biogeographic patterns within the Areceae, it is vital to include all 65 genera of Areceae in this study principally because the characters defining Heterospathe and Rhopaloblaste are shared with several other genera in the tribe. Thus, in this paper, we present not only a phylogenetic assessment of Heterospathe and Rhopaloblaste, but also the first complete generic-level molecular analysis of the entire tribe.

Due to an exceptionally slow rate of plastid DNA evolution in palms in general (Wilson et al., 1990; Asmussen and Chase, 2001), resolution among genera of the Areceae has only been achieved by combining a number of low-copy nuclear markers (Lewis and Doyle, 2002). Low-copy nuclear regions provide some of the most variable and phylogenetically informative molecular markers available, with up to five times the evolutionary rate of plastid DNA, and are especially advantageous in obtaining resolution among rapidly diversifying lineages or at low taxonomic levels (Mort and Crawford, 2004; Small et al., 2004). Although these loci are still not widely used, they promise to be increasingly important in obtaining phylogenetic results at low taxonomic levels, despite potential obstacles relating to molecular evolutionary dynamics, e.g., gene duplications (Mort and Crawford, 2004; Pfeil et al., 2004). In palm systematics, low-copy nuclear loci have been employed with considerable success at a range of taxonomic levels (Lewis and Doyle, 2001, 2002; Norup et al., 2003; Gunn, 2004; Roncal et al., 2005; Thomas et al., 2006, Loo et al., in press).

Intron 4 of $P R K$ and intron 23 of $R P B 2$ were expected to be useful in reconstructing relationships within the Areceae based on promising results from tribes Areceae, Geonomeae and Hyophorbeae (Lewis and Doyle, 2002; Roncal et al., 2005; Thomas et al., 2006; Loo et al., in press). Phosphoribulokinase is a key regulatory enzyme of the Calvin cycle of photosynthetic carbon dioxide assimilation. RNA-polymerase II subunit B codes for the second largest subunit in the RNApolymerase-II complex, the enzyme complex responsible for DNA transcription of protein-coding genes, and is found in all eukaryotes. Across organisms as diverse as humans, Drosophila, fungi, and plants, exon sequences have been shown to be highly conserved and proposed to be valuable in phylogenetic studies (Kawagishi et al., 1993; Denton et al., 1998; Oxelman and Bremer, 2000; Oxelman et al., 2004; Pfeil et al., 2004; Popp and Oxelman, 2004).

The objectives of our study were (1) to evaluate monophyly of Heterospathe and Rhopaloblaste by sampling extensively 
within the two genera and including a complete genus-level sample of the Areceae using the low-copy nuclear DNA regions, intron 4 of $P R K$ and intron 23 of $R P B 2$; (2) to resolve character transformation patterns in key morphological features used to circumscribe Heterospathe and Rhopaloblaste; and (3) to assess biogeographic implications of the phylogenetic relationships of the two genera.

\section{MATERIALS AND METHODS}

Taxon sampling - DNA sequences of 101 taxa were analyzed in this study, including sequences from all 65 genera of tribe Areceae. We sampled down to species level when appropriate to the focus of the paper (sometimes with more than one collection per species); thus we included 16 collections of Heterospathe, five collections of Rhopaloblaste and two species of Ptychosperma, the problematic $P$. micranthum, and the more typical $P$. salomonense Burret. Our sampling was limited only by the remoteness of many of their provenances. The unnamed accessions of Heterospathe collected by Baker represent a range of distinct species, but the inadequacies of available taxonomic treatments preclude assignment of species epithets at this time. Outgroup species consisted of a number of putative near-relatives of the Areceae: Asterogyne martiana (H. Wendl.) H. Wendl., Calyptrogyne costatifrons (L. H. Bailey) Nevers, Geonoma deversa (Poit.) Kunth., Leopoldinia pulchra Mart., Manicaria saccifera Gaertn., Neonicholsonia watsonii Dammer, Pelagodoxa henryana Becc., Pholidostachys pulchra $\mathrm{H}$. Wendl., Sommieria leucophylla Becc.; as well as more distantly related taxa, Podococcus barteri G. Mann \& H. Wendl., Socratea exorrhiza (Mart.) H. Wendl., and Chamaerops humilis L., all selected on the basis of a larger molecular data matrix (W. Baker et al., unpublished data.) and previous studies (Lewis and Doyle, 2002; Norup et al., 2003). We assigned Chamaerops humilis as the ultimate outgroup with which phylogenetic trees were rooted. Complete taxon, voucher, and distribution information (including GenBank accession numbers) is presented in Appendix.

Morphological characters - Ten macromorphological characters pertinent to the delimitation of Heterospathe and Rhopaloblaste were scored at the generic level across the entire taxon sample (Table 1). Characters were taken from descriptions in the literature (Moore et al., 1982; Uhl and Dransfield, 1987; Dowe and Uhl, 1989; Dransfield, 1991; Dransfield and Beentje, 1995; Dransfield and Uhl, 1998) and herbarium specimens, living specimens, and photographs at the Royal Botanic Gardens, Kew. These characters are described in the following section. In some cases, continuous characters could not be readily demarcated objectively (e.g., character 7 , peduncular bract length, which is arbitrarily defined). However, these characters have been used in taxonomic descriptions of these taxa, and therefore it was appropriate to explore them here. Using MacClade, version 4.06 (Maddison and Maddison, 2003) character states were optimized onto one of the most parsimonious trees from the combined analysis.

Leaf character-1. Leaf sheath splitting: splitting to the base (0); remaining entire and tubular for at least three quarters until abscission or marcescence (1). Leaf sheath morphology plays a prominent role in the delimitation of palm genera. In subfamilies Arecoideae and Ceroxyloideae in particular, a distinction is made between species and genera with and without a crownshaft. A crownshaft is present when the leaf sheath is tubular and remains entire, only splitting slightly at the top until senescence, whereupon the sheath splits opposite the petiole along a predetermined line and abscises at the base. The alternative condition is more varied, but typically involves the leaf sheath splitting throughout its length and being open at maturity. A crownshaft is present in most Areceae genera and typically forms part of a broader suite of character states that presumably are functional consequences of strictly tubular leaf sheaths (character 1): inflorescence infrafoliar (character 2), peduncle shorter than the rachis (character 4), prophyll and peduncular bracts caducous (characters 5 and 6), and peduncular bract similar to prophyll or smaller (character 7). These states are not, however, logically dependent on the presence of tubular leaf sheaths, as indicated by the numerous exceptional taxa that do not conform to the typical character state suite.

Inflorescence characters - 2. Inflorescence position: interfoliar (at least in bud) (0); infrafoliar (1). In palms, the most common position of the inflorescence is interfoliar (between the leaves). Within the Areceae, inflorescence position is either interfoliar (as in Heterospathe) or infrafoliar (below the leaves) as in Rhopaloblaste. The infrafoliar condition most often occurs when the inflorescence in bud is exposed by the fall of the subtending leaf and is frequently associated with the presence of a crownshaft.

3. Inflorescence branches in bud: not convoluted (0); convoluted (1). Within the bud, inflorescence branches are typically packed in a linear fashion, but in a few rare cases (e.g., in Rhopaloblaste) in which the inflorescence appears to elongate before it emerges, branches become convoluted.

4. Peduncle length: shorter than rachis (0); longer than (or similar to) rachis (1). Peduncle length is often, but not always correlated with the position of the inflorescence. Thus it is typically elongate when the inflorescence is interfoliar (and must be exserted from the leaf sheaths), and usually short when the inflorescence is infrafoliar. Sometimes (e.g., in some species of Dypsis Noronha ex Mart.) elongate peduncles are found in combination with crownshafts (Dransfield and Beentje, 1995).

5. Prophyll persistence: persistent (0); caducous (1). The prophyll is the first bract on the primary inflorescence axis in palms. It is usually two-keeled and completely encloses the inflorescence during early development. Generally, prophylls of Areceae members abscise at anthesis. However, in a few genera the prophyll persists, e.g., in Brongniartikentia Becc., Heterospathe, and Alsmithia.

6. Peduncular bract persistence: persistent (0); caducous (1). Peduncular bracts are sterile bracts borne above the prophyll, and in most members of Areceae they share a role in protection of the inflorescence in early stages. As with prophylls, peduncular bracts in Areceae members most often abscise at anthesis. However, sometimes the peduncular bract persists, e.g., in species of Heterospathe and Brongniartikentia.

7. Peduncular bract length: longer than prophyll (0); similar to prophyll (or smaller) (1). In most members of tribe Areceae the peduncular bract is enlarged (compared to most other palms) and equals the prophyll, together the two bracts enclosing the inflorescence in bud. In some genera of Areceae, e.g., Heterospathe and Alsmithia, the peduncular bract is much longer than the prophyll.

Fruit and seed characters-8. Endocarp sculpturing: none (0); conspicuous flanges, grooves, ridges (1). Generally the endocarps of Areceae are thin and lack ornamentation. In genera such as Alsmithia, Burretiokentia Pic. Serm., and Veillonia H. E. Moore, however, the endocarp is thickened and intricately sculptured. Although this character is not relevant to the current circumscriptions of Heterospathe and Rhopaloblaste, preliminary analyses of our DNA data sets indicated that it may be of great significance to a revised generic concept in Heterospathe.

9. Endosperm type: homogeneous (0); ruminate (1). Endosperm condition has been considered to have considerable diagnostic value. Palm seeds contain abundant endosperm that can be homogeneous or ruminate (i.e., with folds and invaginations from the seed coat). Rumination can be very variable and, in some cases, polymorphic within species (Zona, 2003).

Seedling character - 10. Eophyll shape: bifid (0); pinnate (1); entire (2). The eophyll is the first expanded leaf produced by a seedling and is in its simplest form undivided. However, in palms with reduplicate leaves (such as members of the Areceae) a bifid eophyll is the most common form. Pinnate eophylls occur in, e.g., Rhopaloblaste and Acanthophoenix H. Wendl.; in the latter, bifid eophylls are also known in some species.

Three characters states, which according to Banka and Baker (2004) are useful in delimitation of Rhopaloblaste, were not incorporated in this analysis, namely, strongly divaricate first-order inflorescence branches, a club-shaped embryo, and an indumentum on the leaf petiole and rachis consisting of multiple, laminar, membranous brownish-black scales. They were excluded due to charactercoding difficulties and lack of adequate comparative data across our samples.

DNA extractions, amplification, and sequencing-DNA was extracted using $0.3 \mathrm{~g}$ silica-gel-dried (Chase and Hills, 1991) or $1.0 \mathrm{~g}$ fresh material and a version of the $2 \times$ CTAB extraction method modified from that of Doyle and Doyle (1987). Before precipitation, a sample was purified with the Qiagen PCR purification kit (Qiagen, Crawley, West Sussex, UK) following the manufacturer's protocol; this was used immediately for PCR. The remaining DNA was then purified on cesium chloride/ethidium bromide gradients $\left(1.55 \mathrm{~g} \cdot \mathrm{L}^{-1}\right.$ density) and dialyzed. These DNA samples are available from the DNA Bank of the Royal Botanic Gardens, Kew (http://www.rbgkew.org. uk/data/dnaBank). 
TABLE 1. Matrix of morphological character states for tribe Areceae and outgruoups. Description of characters and states are given in Materials and Methods, subsection Morphological characters. ?= missing data; - = state not applicable; nos. surrounded by brackets signify polymorphic state assignments. Taxa are followed by a voucher number if there is more than one collection per species or if the species is undetermined.

\begin{tabular}{|c|c|}
\hline Taxa & $\begin{array}{l}\text { Character states for } \\
\text { characters } 1-10\end{array}$ \\
\hline Acanthophoenix rubra & $110011100\{01\}$ \\
\hline Actinokentia huerlimannii & $110011100 ?$ \\
\hline Actinorhytis calapparia & 1100111010 \\
\hline Adonidia merrillii & 1100111010 \\
\hline Alloschmidia glabrata & 1000111000 \\
\hline Alsmithia longipes Baker 1180 & 0001000100 \\
\hline Alsmithia longipes Zona 1039 & 0001000100 \\
\hline Archontophoenix purpurea & 1100111010 \\
\hline Areca catechu & $11001-010$ \\
\hline Asterogyne martiana & 0001010000 \\
\hline Balaka longirostris & 1101110000 \\
\hline Basselinia velutina & 1100111000 \\
\hline Bentinckia condapanna & 1100111100 \\
\hline Brassiophoenix drymophloeoides & 1100111100 \\
\hline Brongniartikentia lanuginosa & $1\{01\} 01110000$ \\
\hline Burretiokentia vieillardii & 1100111100 \\
\hline Calyptrocalyx hollrungii & $000-000000$ \\
\hline Calyptrogyne costatifrons & $000-010000$ \\
\hline Campecarpus fulcitus & 1100111100 \\
\hline Carpentaria acuminata & 1100111000 \\
\hline Carpoxylon macrospermum & 1100111000 \\
\hline Chamaerops humilis & $00000-012$ \\
\hline Chambeyronia macrocarpa & 1100111000 \\
\hline Clinosperma bracteale & $110011100 ?$ \\
\hline Clinostigma savoryanum & 1100111000 \\
\hline Cyphokentia macrostachya & $110011100 ?$ \\
\hline Cyphophoenix nucele & 1100111000 \\
\hline Cyphosperma balansae & 0001000100 \\
\hline Cyrtostachys renda & 1100111000 \\
\hline Deckenia nobilis & 1100111000 \\
\hline Dictyosperma album & 1100111010 \\
\hline Drymophloeus litigiosus & 1100111010 \\
\hline Dypsis lutescens & $1\{01\} 01011000$ \\
\hline Geonoma deversa & $0\{01\} 10 ?\{01\} 1000$ \\
\hline Hedyscepe canterburyana & 1100111000 \\
\hline Heterospathe cagayanensis & 0001000010 \\
\hline Heterospathe delicatula & 0001000010 \\
\hline Heterospathe elata Houg. \& Hubb. 1024 & 0001000010 \\
\hline Heterospathe elata Chapin 55 & 0001000010 \\
\hline Heterospathe elata Lewis 99-034 & 0001000010 \\
\hline Heterospathe humilis & 0001000010 \\
\hline Heterospathe macgregorii & 0001000010 \\
\hline Heterospathe philippinensis & 0001000010 \\
\hline Heterospathe phillipsii & 0001000010 \\
\hline Heterospathe scitula & 0001000010 \\
\hline Heterospathe sibuyanensis & 0001000010 \\
\hline Heterospathe sp. Baker 1115 & 0001000010 \\
\hline Heterospathe sp. Baker 1142 & 0001000010 \\
\hline Heterospathe sp. Banka 2008 & 0001000010 \\
\hline Heterospathe sp. nov. Fernando 1624 & 0001000010 \\
\hline Howea belmoreana & $000-000000$ \\
\hline Hydriastele beguinii & 1100111010 \\
\hline Hydriastele brassii & 1100111010 \\
\hline Hydriastele costata & 1100111000 \\
\hline Hydriastele microspadix & 1100111010 \\
\hline Iguanura wallichiana & 0001000010 \\
\hline Kentiopsis oliviformis & 1100111000 \\
\hline Laccospadix australasicus & $000-000010$ \\
\hline Lavoixia macrocarpa & $110011100 ?$ \\
\hline Lemurophoenix halleuxii & 1100111010 \\
\hline Leopoldinia pulchra & 0001111000 \\
\hline Lepidorrhachis mooreana & 0100111000 \\
\hline
\end{tabular}

TABLE 1. Continued.

\begin{tabular}{|c|c|}
\hline Taxa & $\begin{array}{l}\text { Character states for } \\
\text { characters } 1-10\end{array}$ \\
\hline Linospadix albertisiana & 000-010000 \\
\hline Loxococcus rupicola & 1100111010 \\
\hline Manicaria saccifera & 0001001000 \\
\hline Marojejya darianii & 0001001100 \\
\hline Masoala madagascariensis & 0001001000 \\
\hline Moratia cerifera & 1100111000 \\
\hline Nenga pumila var. pachystachya & $11001-010$ \\
\hline Neonicholsonia watsonii & 000-000010 \\
\hline Neoveitchia storckii & 1100110000 \\
\hline Nephrosperma vanhoutteanum & 0001010010 \\
\hline Normanbya normanbyi & 1100111010 \\
\hline Oncosperma tigillarium & 1100111010 \\
\hline Pelagodoxa henryana & 0001010000 \\
\hline Phoenicophorium borsigianum & 0001000012 \\
\hline Pholidostachys pulchra & $000-\{01\} 10000$ \\
\hline Physokentia rosea & 1100111100 \\
\hline Pinanga coronata & $11001-010$ \\
\hline Podococcus barteri & 0001001001 \\
\hline Ponapea palauensis & 1100111100 \\
\hline Ptychococcus paradoxus & $11001111\{01\} 0$ \\
\hline Ptychosperma micranthum & $11010\{01\} 1010$ \\
\hline Ptychosperma salomonense & 1100111000 \\
\hline Rhopaloblaste augusta & 1110111011 \\
\hline Rhopaloblaste ceramica & 1110111011 \\
\hline Rhopaloblaste ledermanniana Heatubun 191 & 1110111011 \\
\hline Rhopaloblaste ledermanniana Maturbongs 650 & 1110111011 \\
\hline Rhopaloblaste singaporensis & $11 ? 0111011$ \\
\hline Rhopalostylis baueri & 1100111000 \\
\hline Roscheria melanochaetes & $1\{01\} 01000010$ \\
\hline Satakentia liukiuensis & 1100111000 \\
\hline Socratea exorrhiza & 1101110000 \\
\hline Solfia samoensis & 1101111000 \\
\hline Sommieria leucophylla & 0001001000 \\
\hline Tectiphiala ferox & $110011100 ?$ \\
\hline Veillonia alba & $110011010 ?$ \\
\hline Veitchia spiralis & 1100111000 \\
\hline Verschaffeltia splendida & 0001010110 \\
\hline Wodyetia bifurcata & 1100111000 \\
\hline
\end{tabular}

Primers for amplification of PRK (entire intron 4, partial exons 4 and 5) followed Lewis and Doyle (2002); 717F (5'-GTGATATGGAAGAACGTGG$\left.3^{\prime}\right)$ and 969R (5'-ATTCCAGGGTATGAGCAGC-3') are designed to target only paralogue 2 within PRK. Lewis and Martinéz (2000) found two paralogues of $P R K$ in a species-level analysis and reported paralogue 2 to be informative. This paralogue was also employed in the study of Lewis and Doyle (2002). Primers for RPB2 intron 23 followed Roncal et al. (2005): INT23F (5'CAACTTATT GAGTGCATCATGG-3') and INT23R ( $5^{\prime \prime}$-CCACGCATCTGATATCCAC-3'). For PCR amplification, a high-magnesium PCR buffer was used for both $R P B 2$ and $P R K$ (1.1× ReddyMix PCR Master Mix, $2.5 \mathrm{mM}$ $\mathrm{MgCl}_{2}$ ). Reactions included the following: $1-2 \mu \mathrm{L}$ of DNA template, $45 \mu \mathrm{L}$ of 1.1× ReddyMix (Abgene, Epsom, UK), $0.5 \mu \mathrm{L}$ of both forward and reverse primers, and $1 \mu \mathrm{L}$ of bovine serum albumin (BSA). For the amplification of $P R K, 1 \mu \mathrm{L}$ of $2 \%$ dimethylsulfoxide (DMSO) was added to improve amplification success.

Thermocycler conditions employed for $P R K$ amplification were an initial cycle at $94^{\circ} \mathrm{C}$ for 4 mins, 32 cycles of $94^{\circ} \mathrm{C}$ for $1 \mathrm{~min}, 56.5^{\circ} \mathrm{C}$ for $1 \mathrm{~min}$, and $72^{\circ} \mathrm{C}$ for 2 mins. Following the last cycle, we used a final extension at $72^{\circ} \mathrm{C}$ for 7 mins. Amplification of RPB2 was conducted using conditions similar to the above, except for an annealing temperature of $54.5^{\circ} \mathrm{C}$. Some taxa that did not readily amplify were run with a lower annealing temperature $\left(52^{\circ} \mathrm{C}\right.$ for $P R K$, $53^{\circ} \mathrm{C}$ for $R P B 2$ ). All PCR and cycle sequencing reactions were run on a PerkinElmer GenAMP model 9600 or 9700 (Perkin-Elmer, Boston, Massachusets, USA). Following amplification, samples were purified using Qiagen PCR purification kit (Qiagen) following the manufacturer's protocol. Purified DNA fragments were sequenced using the PCR primers and the BigDye Terminator Mix v. 3.0 (Applied Biosystems, ABI, Warrington, Cheshire, UK) following the manufacturers protocol. The sequencing protocol consisted of 26 cycles of 
$10 \mathrm{sec}$ denaturation $\left(96^{\circ} \mathrm{C}\right), 5 \mathrm{sec}$ annealing $\left(50^{\circ} \mathrm{C}\right)$, and 4 min elongation $\left(60^{\circ} \mathrm{C}\right)$. The cleaned cycle-sequencing products were analyzed on an ABI 377 automated sequencer, according to the manufacturer's protocols. Both strands were sequenced for each region for all taxa.

In six taxa, two for $P R K$ and four for $R P B 2$, amplification results were poor or yielded electropherograms that indicated the presence of multiple copies of the target sequence. Such PCR products were cloned using pGEM-T Easy Vector System (Promega, Chilworth Science Park, Southampton, UK) following the manufacturer's protocol. Transformed cells were grown on solid LB medium, and five transformed colonies per cloned taxon were sampled for PCR by inoculating PCR reactions with transformed cells as template.

Alignment and phylogenetic analysis-Sequences were edited and assembled using Sequencer 4.1.2 software (Gene Codes, Ann Arbor, Michigan, USA). All sequences, including some previously published by Lewis and Doyle (2002), were aligned by eye in PAUP, version $4.0 \mathrm{~b} 10$ for Macintosh (Swofford, 2002). Ambiguous parts of the alignment (e.g., some rather large homopolymer regions) and parsimony uninformative characters were excluded from the analysis. Matrices can be downloaded from TreeBase (http://www. treebase.org). Cladistic analyses were conducted with PAUP* using maximum parsimony. All character changes were treated as unordered and equally weighted (Fitch, 1971). Indels were treated as missing data.

The data partitions were analyzed separately and simultaneously. Preliminary searches yielded extremely large numbers of equally parsimonious resolutions, a problem exacerbated by the presence of zero length branches. These searches could not, in practice, be run to completion. Thus, a pragmatic strategy similar to that used by Asmussen and Chase (2001) was followed: 1000 replicates of random taxon addition were performed using tree-bisectionreconnection (TBR) branch swapping with 25 trees held at each step; trees found in these 1000 replicates were then used as starting trees for a second search using TBR branch swapping until a pre-set maximum of 20000 trees were reached. These trees were then swapped to completion. Support for clades was assessed using the bootstrap (Felsenstein, 1985) as implemented in PAUP* using 500 replicates of simple taxon addition, TBR swapping, and a limit of 10 trees saved in each replicate (Salamin et al., 2003).

The $P R K$ and $R P B 2$ data sets were examined for congruence using the partition homogeneity test implemented in PAUP* (Farris et al., 1995; 100 replicates, saving 10 trees per replicate). However, because this method has been shown to be unreliable (Dolphin et al., 2000; Reeves et al., 2001; Yoder et al., 2001), a "hard" incongruence test was also performed by directly comparing topologies from the separate analyses with respect to resolution and bootstrap support (i.e., looking for incongruent clades with bootstrap percentages (BP) >85; Wiens, 1998; Sheahan and Chase, 2000).

\section{RESULTS}

PRK and RPB2 Clones-Five or more clones were sequenced for two of the six taxa for which heterogeneity was observed, namely Brongniartikentia lanuginosa $\mathrm{H}$. E. Moore and Veillonia alba H. E. Moore for PRK. Comparisons between the clones revealed that, although different versions of the target sequence occurred within species, they differed in only a very small number of substitutions and a few short indels; these most likely represented alleles or recent paralogy because they all resolved as monophyletic groups in preliminary analyses. For the purposes of this study, therefore, one clone was selected at random for inclusion in the analyses. For the remaining four taxa for RPB2, Cyphokentia macrostachya Brongn., Heterospathe phillipsii D. Fuller \& Dowe, Marojejya darianii J. Dransf. \& N. Uhl and Roscheria melanochaetes $\mathrm{H}$. Wendl., only one clone was obtained.

PRK analysis - The final alignment included 800 positions; 119 positions were excluded as ambiguously aligned because they consisted of microsatellite motifs or long homopolymer regions. Of the remaining characters, 206 (30.2\%) were potentially parsimony informative (Table 2). In Heterospathe,
TABLE 2: Statistics from phylogenetic analyses of $P R K, R P B 2$, and combined matrices for tribe Areceae and outgroups. $\mathrm{CI}=$ consistency index; $\mathrm{RI}=$ retention index.

\begin{tabular}{lccc}
\hline \hline \multicolumn{1}{c}{ DNA region } & $P R K$ & $R P B 2$ & Combined \\
\hline No. of taxa & 101 & 100 & 100 \\
Aligned length & 800 & 1301 & 2101 \\
No. potentially & & & \\
$\quad$ informative characters & $206(30.2 \%)$ & $257(22.3 \%)$ & $463(25.2 \%)$ \\
No. trees & 20000 & 20000 & 20000 \\
Tree length & 581 & 674 & 1291 \\
CI & 0.51 & 0.58 & 0.53 \\
RI & 0.71 & 0.71 & 0.69 \\
No. of clades with & & & \\
$\quad \geq 85 \%$ bootstrap & 19 & 26 & 38 \\
No. of clades with & & & 62 \\
$\quad \geq 50 \%$ bootstrap & 44 & 47 & 62 \\
\hline
\end{tabular}

the $P R K$ intron was almost consistently about half the length of the region in other palms. Although this feature represents a character linking the species of Heterospathe together, it is potentially problematic because it reduces information available for the group. Analyses produced 20000 trees (the pre-set limit) with a length of 581, a CI of 0.51 and a RI of 0.71 . The strict consensus tree with bootstrap percentages is shown in Fig. 1.

The Areceae (99 bootstrap percentage, BP), outgroup tribe Geonomateae (Asterogyne H. Wendl., Geonoma Willd., Calyptrogyne H. Wendl., Pholidostachys H. Wendl.; 87 BP), the New World tribes Leopoldinieae (Leopoldinia), Manicarieae (Manicaria) and Euterpeae (Neonicholsonia), and the Pacific tribe Pelagodoxeae (Pelagodoxa, Sommieria; 100 BP) form a moderately supported clade (78 BP), but the relationships among these tribes are unclear. The topology supports the exclusion of Pelagodoxeae from Areceae.

Within the Areceae, a substantial clade consisting mainly of western Pacific and Australian genera from subtribes Archontophoenicinae, Basseliniinae, Carpoxylinae, Clinospermatinae, Linospadicinae, Ptychospermatinae, and Rhopalostylidinae, as well as several genera as yet unplaced to subtribe, is resolved, corresponding to the south-western Pacific and Australia clade of Lewis and Doyle (2002). This clade is hereafter termed the western Pacific clade. We recover only weak support for the group here (61 BP), and within it there is a large polytomy. One Indian Ocean genus, Loxococcus $\mathrm{H}$. Wendl. \& Drude from Sri Lanka, is included at the basal polytomy of the western Pacific clade. Subtribe Ptychospermatinae excluding Ptychosperma micranthum is weakly supported (clade wp3; $60 \mathrm{BP}$ ). Ptychosperma micranthum falls at the basal polytomy of the western Pacific clade. The monophyly of two other western Pacific subtribes Clinospermatinae (clade wp4; $98 \mathrm{BP}$ ) and Carpoxylinae (clade wp6; $<50 \mathrm{BP}$ ) is also resolved. Subclades of a number of other subtribes are resolved, such as a group consisting of all members of subtribe Linospadicinae except Calyptrocalyx Blume (clade wp5; 75 BP).

Within the large western Pacific clade, all members of Heterospathe form a monophyletic group (72 BP) with the monotypic genus Alsmithia from Fiji, within which there is a basal polytomy such that the monophyly of neither genus is confirmed. Thus, the Philippine endemics $H$. cagayanensis Becc. and $H$. sibuyanensis Becc. are supported by $83 \mathrm{BP}$, in a group ( $<50 \mathrm{BP}$ ) otherwise consisting of the widespread $H$. elata Scheff. and an undescribed Philippine species (Fernando 


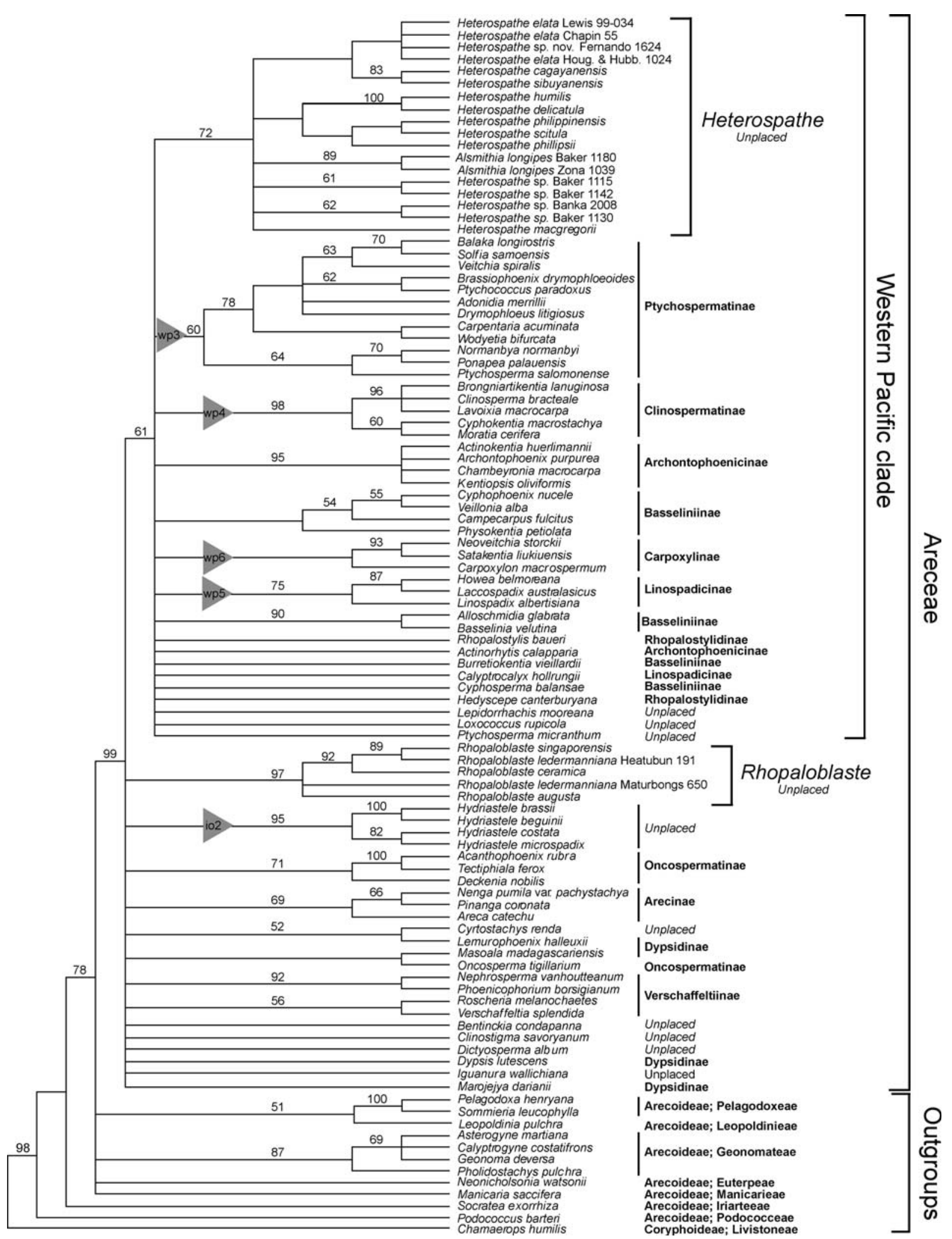

Fig. 1. Strict consensus tree resulting from parsimony analysis of the $P R K$ data set for tribe Areceae and outgroups. Bootstrap percentages $>50 \%$ are indicated above the branches. Herbarium vouchers are indicated for clarity where necessary. Significant clades that appear in the combined analysis are marked with triangles. Higher level ranks follow the classification of Dransfield et al. (2005). Genera of Areceae that are not yet placed to subtribe by Dransfield et al. (2005) are indicated. 
1624). A clade (100 BP) of the New Guinean species $H$. delicatula $\mathrm{H}$. E. Moore and H. humilis Becc. is resolved within a clade $(<50 \mathrm{BP})$ containing the Philippine species, $H$. philippinensis Becc. and $H$. scitula Fernando plus the Fijian H. phillipsii.

Rhopaloblaste is a strongly supported monophyletic group (97 BP) outside the western Pacific clade. Rhopaloblaste ceramica (Miq.) Burret, R. ledermanniana Becc. (Heatubun 191), and R. singaporensis (Becc.) Hook. f. are supported by $92 \mathrm{BP}$. The second accession of $R$. ledermanniana (Maturbongs 650) plus R. augusta (Kurz) H. E. Moore are not clearly resolved.

Most genera that resolve outside the western Pacific clade along with Rhopaloblaste are distributed in the Indian Ocean through to Malesia, and belong to subtribes Arecinae, Dypsidinae, Oncospermatinae, and Verschaffeltiinae or are as yet unplaced to subtribe. Of these subtribes, only the Arecinae is resolved as monophyletic here (69 BP).

RPB2 analysis - The final alignment had a total length of $1301 \mathrm{bp} ; 148$ characters were excluded as ambiguously aligned due to microsatellite motifs or long homopolymer regions. Of the remaining positions, $257(22.3 \%)$ were potentially parsimony informative (Table 2). Analysis produced 20000 trees (the pre-set limit) with a length of 674 , a CI of 0.58 and a RI of 0.71 . The strict consensus tree with bootstrap percentages is shown in Fig. 2. No RPB2 sequence was produced for Heterospathe sp. Baker 1130, and hence this analysis includes only 15 accessions for the genus.

Outgroup taxa are similarly arranged as in the $P R K$ trees, but with slightly better resolution, although only a few groups are well-supported. Again, the topology supports the exclusion of Pelagodoxeae from Areceae. The Areceae is strongly supported (95 BP), although relationships within the clade are highly unresolved. The western Pacific clade is not recovered in this topology and only two subtribes, Clinospermatinae (clade wp4; $66 \mathrm{BP}$ ) and Carpoxylinae (clade wp6; $88 \mathrm{BP}$ ), are resolved as monophyletic. However, numerous subclades from various subtribes are resolved.

All species of Heterospathe form a clade, but it is weakly supported $(<50 \mathrm{BP})$. There are within this clade two strongly supported subclades (1 and 2; 99, 98 BP, respectively). Clade 1 consists mainly of Philippine and Fijian species plus two species from New Guinea (H. delicatula and $H$. humilis). The other clade (2) contains New Guinean species only. The Fijian Alsmithia is, unlike in the PRK analysis, clearly nested within Heterospathe, in this case within the strongly supported clade 1. Also within clade 1, a weakly supported group (64 BP) contains all Philippine species plus the widespread $H$. elata. The New Guinean species, $H$. humilis and $H$. delicatula, form a strongly supported pair (94 BP).

Rhopaloblaste is again robustly resolved as monophyletic group (100 BP), within which $R$. singaporensis and $R$. ledermanniana (Heatubun 191) form a strongly supported pair (99 $\mathrm{BP}$ ). The second accession of $R$. ledermanniana (Maturbongs 650 ) is resolved in an ambiguous position within the clade. A relationship not seen in the $P R K$ tree is the strongly supported sister group relationship of Rhopaloblaste with the monotypic Mascarene genus, Dictyosperma H. Wendl. \& Drude (96 BP).

Combined analysis-According to the partition homogeneity test, the two data sets were significantly incongruent $(P=0.01)$. However, comparing the single-gene topologies on a node-by-node basis, which may give a better assessment of congruence than the sometimes unreliable partition homogeneity test (Dolphin et al., 2000; Reeves et al., 2001; Yoder et al., 2001), did not result in any highly supported, incongruent relationships $(>85 \mathrm{BP})$. We have therefore chosen to combine the two datasets due to the generally high level of congruence between the single-gene trees. The increased number of wellsupported clades resulting from analysis of the combined dataset relative to the separate data partitions (Table 2) lends further weight to our assertion that the two datasets are broadly congruent.

Due to the lack of an RPB2 sequence for Heterospathe sp. Baker 1130, this accession was left out of the combined analysis. Analysis of the combined matrix produced 20000 trees with a length of 1291, a CI of 0.53 and a RI of 0.69 (Table 2). One of the most parsimonious trees is shown in Fig. 3.

The combination of the two datasets resulted in a substantial increase in both resolution and numbers of nodes supported by the bootstrap (Table 2), especially within the Areceae. As found in the RPB2 analysis, outgroup relations are well resolved. The topology moderately supports a large clade $(90$ BP) broadly comparable to relationships recovered by Lewis and Doyle (2002) composed of the following groups: Areceae (100 BP), Euterpeae, Geonomateae (100 BP), Leopoldinieae and Pelagodoxeae (100 BP). The New World tribe Manicarieae is strongly supported as sister to this clade (92 BP). The combined analysis supports the exclusion of Pelagodoxeae from Areceae, as did the individual data partitions.

The clade of Areceae is divided into two major subclades (Fig. 3), although neither is well-supported. The first clade $(<50 \mathrm{BP})$ comprises genera occurring in the islands and continental regions of the Indian Ocean through Malesia to New Guinea, a few of which also extend into the western Pacific (Cyrtostachys, Hydriastele, Rhopaloblaste, and Clinostigma $\mathrm{H}$. Wendl.) and is hereafter referred to as the Indian Ocean clade. The second clade (the western Pacific clade; 63 BP) consists of genera from the Philippines, the Moluccas, and New Guinea through to Australia, New Caledonia, and the Areceae's easternmost limit in Samoa. The monotypic genus Loxococcus from Sri Lanka is supported as sister to the western Pacific clade (66 BP). Relationships within these two major clades are poorly resolved, but include several major groups of interest.

Within the Indian Ocean clade, only the Arecinae is resolved as monophyletic (87 BP). Three of the four genera of subtribe Dypsidinae resolve in a clade with Iguanura (clade io4; $<50$ BP). Subclades of subtribes Verschaffeltiinae and Oncospermatinae form a group (io1; <50 BP), with other constituent genera forming relationships elsewhere. Although these results call into question the monophyly of Dypsidinae, Oncospermatinae and Verschaffeltiinae, none of the relevant relationships is well supported.

Within the western Pacific clade, four of the five genera of Archontophoenicinae (Actinokentia, Archontophoenix, Chambeyronia, Kentiopsis) constitute a strongly supported group (100 BP) within clade wp2. Most members of subtribe Linospadicinae (excluding Calyptrocalyx) form a strongly supported clade (clade wp5; 100 BP). Subtribes Carpoxylinae (clade wp6; 96 BP) and Clinospermatinae (clade wp4; 100 BP) are strongly supported as monophyletic. Ptychospermatinae form a clade (clade wp3; $72 \mathrm{BP}$ ) that excludes Ptychosperma micranthum, which resolves as sister to clade wp4. Subclades of Basseliniinae receive bootstrap support within clades wp1 


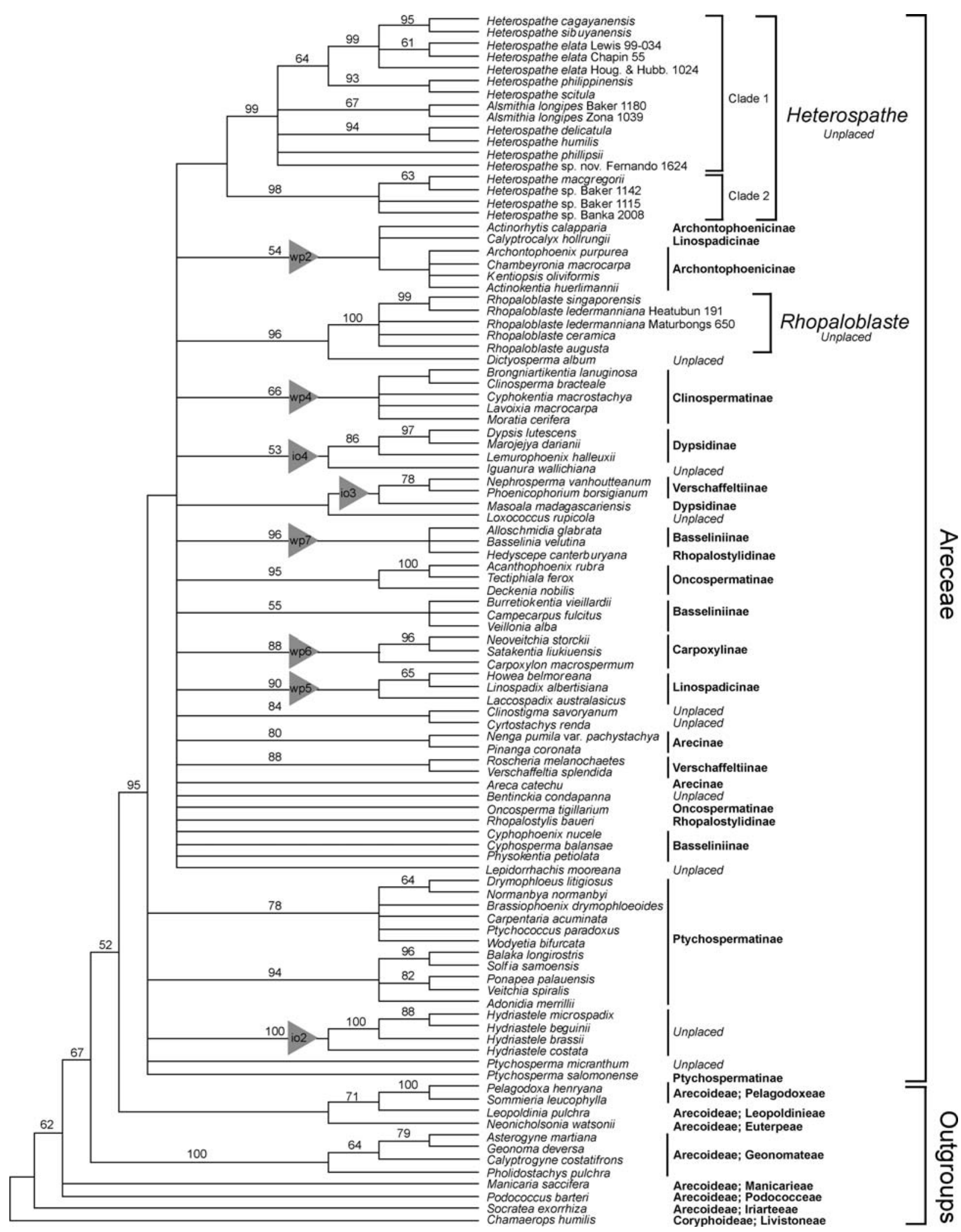

Fig. 2. Strict consensus tree resulting from parsimony analysis of the RPB2 data set for tribe Areceae and outgroups. Bootstrap percentages $>50 \%$ are indicated above the branches. Within Heterospathe, clade 1 comprises mainly Philippine and Fijian species and clade 2 consists of New Guinean species. See Results: RPB2 analysis for further information. See Fig. 1 legend for an explanation of annotations. 


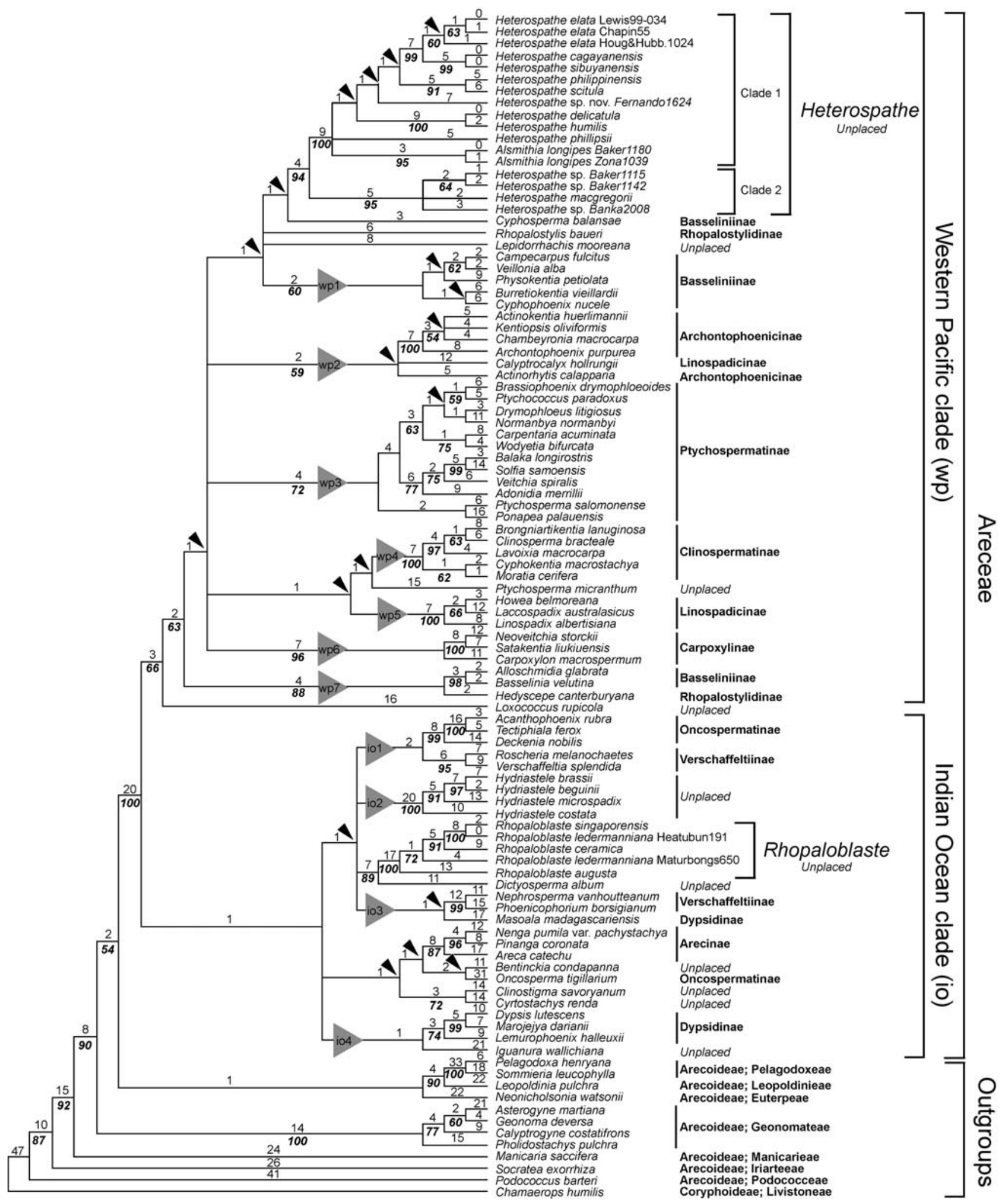

Fig. 3. One of the most parsimonious trees from the combined analysis of $P R K$ and $R P B 2$ data for tribe Areceae and outgroups (length $=1291$; $C I=$ $0.53 ; \mathrm{RI}=0.69)$. Branch lengths under DELTRAN optimization are indicated above the branches. Bootstrap percentages $>50 \%$ are indicated below the branches. Branches that collapse in the strict consensus tree are indicated by arrows. See Fig. 1 legend for an explanation of annotations. 
(60 BP) and wp7 (98 BP), but the subtribe is not resolved as monophyletic.

All included members of Heterospathe resolve within the western Pacific clade as a strongly supported clade (94 BP) with the monotypic genus Alsmithia firmly nested inside. Within the Heterospathe-Alsmithia group, two clades with moderate to strong bootstrap support are found, consisting of (1) species occurring from the Philippines through to Fiji (clade 1,100 BP) and (2) only species from New Guinea (clade 2, 95 $\mathrm{BP})$. In clade 1 , the widespread $H$. elata is resolved within a strongly supported clade (99 BP) also containing a group consisting of the two Philippine endemics, H. cagayanensis and $H$. sibuyanensis (99 BP). The two New Guinean species $H$. delicatula and $H$. humilis are resolved within clade 1 supported by $100 \mathrm{BP}$.

The five species of Rhopaloblaste are resolved within the Indian Ocean clade supported by $100 \mathrm{BP}$ and with a strongly supported relationship (89 BP) to the monotypic Mascarene genus Dictyosperma. Complete resolution in this part of the consensus tree shows the first split to be between Rhopaloblaste augusta from Nicobar Island and a moderately supported group (72 BP) consisting of $R$. ledermanniana and $R$. ceramica (New Guinea and the Moluccas), plus $R$. singaporensis (peninsular Malaysia and Singapore). Within this group, $R$. singaporensis and $R$. ledermanniana (Heatubun 191) are strongly supported (100 BP) as sisters, with a well-supported relationship to $R$. ceramica. Rhopaloblaste ledermanniana (Maturbongs 650) is resolved separately from the other accession of $R$. ledermanniana.

\section{DISCUSSION}

Phylogenetic value of PRK and RPB2-The level of variation in the low-copy nuclear genes $P R K$ and $R P B 2$ is significantly higher than that of the plastid genes used so far in palm phylogenetic studies. For example, the number of informative characters obtained for three plastid markers in a family-wide survey of palms ranged from 6-10\% only (Asmussen and Chase, 2001), whereas PRK and RPB2 yield $30.2 \%$ and $22.3 \%$, respectively, in our study, despite the narrower taxonomic range of our sampling. However, consistency and retention indices are still relatively low, indicating an elevated number of homoplasious characters. Introns of plastid DNA seem to contain the least homoplasy reported for regions used in analyses of the palm family (e.g., for 94 taxa, RI $=0.89$ for the rpsl6 intron; Asmussen and Chase, 2001), but as mentioned above, they also contain a lower percentage of parsimony informative characters. In contrast, other nuclear ribosomal DNA regions like ITS and $5 \mathrm{~S}$ spacer contain a high number of informative characters, but also high levels of homoplasy. In recent studies by Baker et al. $(2000 \mathrm{~b}, \mathrm{c})$ on the palm subfamily Calamoideae, values of RI varied between 0.39 (60 taxa, 415 informative characters) and 0.62 (108 taxa, 469 informative characters) for ITS, and between 0.48 (41 taxa, 267 informative characters) and 0.66 (77 taxa, 352 informative characters) for 5S. High levels of polymorphism within individuals were also discovered in these two multi-copy regions, rendering them relatively unappealing for phylogenetic reconstruction.

It is recognized that even if the partition homogeneity is rejected, combining data sets can still give more accurate phylogenetic estimates (Huelsenbeck et al., 1996; Wiens,
1998). The difference in the phylogenetic histories can potentially affect parts of the combined tree, but the overall accuracy may be increased by the larger number of characters applied to those parts of the tree unaffected by the mismatch (Wiens, 1998). We regard the fact that the combination of the two datasets resulted in a substantial increase in both resolution and numbers of nodes supported by the bootstrap as strong support for simultaneous analysis. It suggests that the significant incongruence identified by the partition homogeneity test is spurious and potentially a result of high levels of noise in the dataset (Dolphin et al., 2000).

This study has identified many new relationships within the Areceae and provided a more resolved and strongly supported estimate of the phylogeny relative to previous analyses that have included genera of Areceae (e.g., Asmussen and Chase, 2001; Lewis and Doyle, 2002; Asmussen et al., in press). It has also demonstrated that $P R K$ and $R P B 2$ are capable of resolving relationships at high taxonomic levels (i.e., between tribes and subtribes) as well as at lower levels between closely related species. Unfortunately, a lack of resolution and bootstrap support leaves large areas of ambiguity in the tree that will have to be addressed before the classification, relationships, and evolutionary history of the Areceae can be fully appreciated.

Monophyly of Heterospathe and Rhopaloblaste-Our results demonstrate that the species of Rhopaloblaste form a strongly supported clade and are clearly not related to Heterospathe. The generic delimitations of Moore (1970) and Uhl and Dransfield (1987) are thus largely confirmed and wellestablished, despite the previous taxonomic confusion.

The species of Heterospathe are resolved as a strongly supported monophyletic group that also includes the monotypic Fijian genus Alsmithia. Several recent studies have indicated that some changes in generic delimitation will be necessary within tribe Areceae (Lewis and Doyle, 2002; Baker and Loo, 2004). In our study, the close relationship between the two genera is well-supported by the DNA analyses, not only by the combined dataset, but also by both datasets individually. The possibility of this relationship being the result of a technical error was ruled out by inclusion of two independent collections of Alsmithia.

Philippine species of Heterospathe-A full monograph of Heterospathe has yet to be undertaken and so far only the Philippine species have been revised. In other parts of its range (e.g., Papuasia), species limits are not clear, and relationships within the genus as a whole are not yet assessed. The results of our molecular analyses are congruent with the recent revision of Heterospathe from the Philippines (Fernando, 1990a, b). Fernando noted that the widespread $H$. elata (occurring in the Philippines, the Moluccas, Guam, and Palau Island) is morphologically most similar to the island endemics $H$. sibuyanensis and $H$. cagayanensis, due to their shared robust habits and large inflorescences; this relationship is reflected in our combined analysis (99 BP). Differences between $H$. elata and $H$. sibuyanensis are limited, and only the shape of fruits and seeds seem to distinguish these two species. In his revision, Fernando (1990b) noted that $H$. sibuyanensis is known only from the type specimen, and he retained the species as distinct only because of the absence of more herbarium material from the type locality. However, we question the identity of the DNA source, a cultivated palm originating far from the type 
locality in Quezon Province. Unfortunately, the lack of fertile material precludes confirmation at this time, although sterile material closely resembles $H$. elata. Fernando furthermore described the Luzon endemic $H$. scitula as having the greatest resemblance to $H$. philippinensis (and $H$. dransfieldii Fernando, not included in this analysis), but differing in its neatly abscising leaves and shorter leaflet pairs and a seemingly infrafoliar inflorescence. This relationship is supported by 91 $\mathrm{BP}$ in our combined analysis.

Relationships between Heterospathe, Rhopaloblaste, and other members of the Areceae-The monotypic Mascarene genus Dictyosperma is resolved with strong support as the nearest relative to Rhopaloblaste (89 BP). Uhl and Dransfield (1987) regarded the relationships of Dictyosperma as unclear, but noted that it was possibly related to Clinostigma, which is not supported by our analyses. Geographically, Rhopaloblaste and Dictyosperma are far separated, but morphological similarities between Dictyosperma and Rhopaloblaste do exist, e.g., the primary inflorescence branches of Dictyosperma become divaricate with age and are thus reminiscent of those in Rhopaloblaste. No such close relationship between Heterospathe and any of the other genera, apart from Alsmithia, is identified.

Higher-level relationships within the Areceae-The high support for the Areceae corroborates previous results (Hahn, 2002; Lewis and Doyle, 2002) and supports the exclusion of Pelagodoxeae from the tribe. Our study highlights some of the limitations of the previous classification (Uhl and Dransfield, 1987; Dransfield and Uhl, 1998), such as the non-monophyly of the large subtribe Iguanurinae, which is not accepted in the revised classification of Dransfield et al. (2005). It provides support for the delimitation of several subtribes recognized in the revised classification, principally Arecinae, Carpoxylinae, Clinospermatinae and Ptychospermatinae. Though the monophyly of the remaining subtribes of Areceae (Archontophoenicinae, Basseliniinae, Dypsidinae, Oncospermatinae, Rhopalostylidinae, and Verschaffeltiinae) is not supported, neither is strong support for their non-monophyly obtained. The sole exception to this generality is the curious relationship between Hedyscepe and the clade Alloschmidia and Basselinia, which is highly supported by the combined analysis (88 BP) and thus contradicts the monophyly of the Rhopalostylidinae.

Morphological characters-All morphological characters included in the study were homoplasious (Appendix S1; see Supplementary Data accompanying online version of this article). Such high levels of homoplasy have been reported several times for large and species-rich plant groups in the tropics (e.g., Moylan et al., 2004; Tam et al., 2004). Within the palm family, a recent study of subfamily Calamoideae found many of the characters previously used to delimit subtribes and genera of Calamoideae to be highly homoplasious (Baker et al., 2000a). Other palm genera that have been previously reported to be characterized by a combination of characters that are homoplasious include Sommieria and Pelagodoxa (Stauffer et al., 2004) and Ptychococcus Becc. (Zona, 2003).

Of the suite of characters associated with the crownshaft, only the presence of tubular leaf sheaths is unequivocally synapomorphic for the Areceae. Three of the remaining characters (infrafoliar inflorescences, caducous prophylls, and peduncles shorter than the rachis) optimize equivocally at the
Areceae node, though are potentially synapomorphic for the group under some alternative optimizations (Appendix S1; see Supplementary Data accompanying online version of this article). However, these crownshaft characters are highly homoplasious with several occurrences outside the Areceae (e.g., Chamaedoreeae, Cyclospatheae, Iriarteeae, Roystoneae) and numerous correlated reversals, resulting in a substantial number of genera without crownshafts (leaf sheath splitting to the base) that also bear interfoliar inflorescences with persistent or marcescent prophylls and peduncles that greatly exceed the rachis (Alsmithia, one species of Brongniartikentia, Cyphosperma, Heterospathe, Iguanura, Nephrosperma, Phoenicophorium, Verschaffeltia, some species of Dypsis, Masoala, Marojejya Humbert, Calyptrocalyx, Howea, Laccospadix, and Linospadix; character four is inapplicable to last four genera). Our findings must be interpreted within the context of our choice of outgroups; a different selection (e.g., replacing Neonicholsonia with a crownshafted member of Euterpeae) may have yielded alternative optimizations at the Areceae node.

The remaining character states linked to the crownshaft (peduncular bract caducous; peduncular bract similar in length to prophyll or shorter) are not synapomorphic for the Areceae. Both states are widespread across our sample and plesiomorphic in the Areceae, suggesting that they may not be entirely dependent on the occurrence of a crownshaft as suspected initially. Although neither character provides a synapomorphy for the Areceae, they are both clearly closely linked to transformations in other members of the crownshaft character suite. Thus, we have demonstrated a high degree of correlation among the states that comprise the complex morphologies associated with the crownshaft. Such a strong correlation reflects the functional interdependence of these states. For example, the maturation of an inflorescence is hindered by a strictly tubular leaf sheath and can only proceed to anthesis on abscission of the subtending leaf; the inflorescence is thus exposed and presented in an infrafoliar position. Although exceptions occur, e.g., in Dypsis lutescens, this correlation holds true in the majority of cases.

This study indicates that Heterospathe, including Alsmithia, can be diagnosed by a combination of character states that are homoplasious within the Areceae: leaf sheath splitting to the base, interfoliar inflorescences (at least at anthesis), peduncle longer than the rachis, peduncular bract longer than the prophyll, prophyll persistent, and peduncular bracts persistent. It is remarkable that the monophyly of a genus with such ambiguous morphology is so highly supported by molecular data. This combination does not preclude confusion with a small number of other genera of Areceae, namely Brongniartikentia [B. vaginata (Brongn.) Becc. only], Cyphosperma, Iguanura, and Phoenicophorium. However, these genera are readily distinguished on the basis of characters outside our data set, for example, didymous anthers in Brongniartikentia (which also has a crownshaft in $B$. lanuginosa and some individuals of B. vaginata; Pintaud and Hodel, 1998), an incomplete prophyll in Cyphosperma, praemorse leaflets in Iguanura, and spiny leaves in Phoenicophorium. Of these genera, only the geographical range of Cyphosperma overlaps with that of Heterospathe and Alsmithia. Notably, in the most parsimonious tree selected for exploring character optimization, Cyphosperma is sister to the Heterospathe-Alsmithia clade, and thus the character states listed before are optimized at the common node of 
Heterospathe, Alsmithia, and Cyphosperma rather than at the basal node of the Heterospathe-Alsmithia clade. However, this relationship is not present in the strict consensus trees of any of our analyses.

The optimization of character nine (endosperm type) yields numerous independent transformations between the two states, homogeneous and ruminate, underscoring the labile nature of this condition. Ruminate endosperm was a defining character of Heterospathe in its delimitation according to Uhl and Dransfield (1987). Since 1987, however, a species of Heterospathe has been recorded with homogeneous endosperm (H. uniformis Dowe; Dowe and Cabalion, 1996). Furthermore, Alsmithia has homogeneous endosperm. Palm genera that include both ruminate and homogeneous species are well known (e.g., Phoenix L., Reinhardtia, Hydriastele, and Calyptrocalyx), but more recently infraspecific variation in this character has also been documented in Ptychococcus (Zona, 2003).

In addition to its homogeneous endosperm, Alsmithia deviates from Heterospathe in its highly sculptured endocarp (character eight) that is more reminiscent of those found in other western Pacific genera, such as Burretiokentia, Veillonia, and Cyphosperma, rather than the smooth endocarps typical of Heterospathe. However, Essig et al. (1999) noted some similarity between the pericarp composition in Alsmithia and Heterospathe (in particular $H$. woodfordiana Becc.) in that they both possess an expanded series of vascular bundles. A similar example is also seen in the coryphoid palm Licuala Wurmb. in which some New Guinean species have developed a thick and highly ornamented endocarp, probably as an adaptation to specific dispersers (Barfod, 2000; Barfod et al., 2001). Optimization of this character suggests that ornate endocarps have arisen independently at least six times within the Areceae. Whether the developmental origin of endocarp sculpturing is the same in all Areceae genera is unknown and merits further investigation. From the limited material available to us, we suspect that the so-called endocarp of Alsmithia may in fact consist of hardened, elaborated mesocarp fibers. Regardless of this autapomorphy, the molecular evidence in combination with the numerous morphological similarities strongly supports the inclusion of Alsmithia in Heterospathe (Norup, 2005).

Despite possessing the suite of crownshaft character states that is common to so many Areceae genera, Rhopaloblaste is in fact well defined morphologically. In contrast to Heterospathe, two almost uncontradicted synapomorphies have been identified for the genus: inflorescence branches convoluted in bud and a pinnate eophyll. Outside the Areceae, convoluted inflorescence branches are known to occur in species of Geonoma and a small number of other New World palms. Pinnate eophylls are unique to Rhopaloblaste and Acanthophoenix in the Areceae, but are also found outside the clade, e.g., in Podococcus. However, this combination is not shared by any other Areceae genus. Several additional characters not included in our study can be added (Banka and Baker, 2004): an indumentum on the leaf rachis and petiole consisting of multiple laminar, membranous brownish-black scales; strongly divaricate primary inflorescence branches; and a club-shaped embryo.

As well as showing no phylogenetic relationship to Heterospathe and Rhopaloblaste, the problematic taxon Ptychosperma micranthum does not conform to the character combinations previously listed or those of the genus Ptychosperma, indicating that the placement of this species within these three genera by previous authors was in error. The similarity to Heterospathe is limited to the persistence of the prophyll and a ruminate endosperm. Ptychosperma micranthum possesses none of the characters of Rhopaloblaste just listed and differs from Ptychosperma in, among other characters, its persistent rather than caducous prophyll and acute rather than praemorse leaflets. Crownshafted palms that possess persistent prophylls, such as $P$. micranthum, are rare and found only in Roscheria and some species of Dypsis and Drymophloeus Zipp. Our analysis demonstrates that $P$. micranthum is not related to any of these genera. Morphologically, it is readily distinguished from Roscheria in being unarmed rather than spiny, from Drymophloeus in bearing acute rather than praemorse leaflets, and from Dypsis in fruits bearing apical rather than basal stigmatic remains. The phylogenetic and morphological evidence presented here provides an unequivocal justification for the new genus Dransfieldia that has recently been erected to accommodate P. micranthum (Baker et al., 2006).

Biogeographical implications of the analysis for Heterospathe and Rhopaloblaste-The high resolution at the species level within Heterospathe and Rhopaloblaste makes it possible to explore the biogeographic implications of their modern distribution. We tentatively suggest that Rhopaloblaste is of Indian Ocean origin, given its placement in the Indian Ocean clade, its sister group relationship to Dictyosperma from the Mascarenes, and the position of $R$. augusta from Nicobar Island, with subsequent dispersal eastwards into Malesia and Papuasia. The position of $R$. singaporensis could indicate a later dispersal back westward, possibly from New Guinea. However, in the absence of the remaining two species of Rhopaloblaste ( $R$. gideonii R. Banka from New Ireland and $R$. elegans H. E. Moore from the Solomon Islands) this scenario remains speculative. Optimal conditions for dispersal across Wallace's Line from New Guinea back to Peninsular Malaysia occurred in the Tertiary at the boundary between Miocene and Pliocene when a dispersal route was opened by the coherent landmasses that formed the Banda and Sunda arcs (Hall, 1998). Other possibilities to account for the present disjunct distribution include extinction, long-distance dispersal, or inadequate knowledge of the genus in the intervening areas, e.g., in Sulawesi.

Due to the small sample size in this study, conclusions on evolutionary and biogeographic patterns of Heterospathe are preliminary. As shown in Fig. 3, Heterospathe falls within the western Pacific clade. The two clades within Heterospathe have distinct geographies. Clade 1 consists of the Philippine species and the two New Guinean species, $H$. humilis and $H$. delicatula, as well as the Fijian $H$. phillipsii and Alsmithia longipes. These patterns cannot be explained by vicariance events and almost certainly represent dispersal events. In contrast, clade 2 is endemic to New Guinea. The following geological events described by Burrett et al. (1991) and Hall (1998) may have influenced this radiation and present-day distribution of Heterospathe: (1) Fiji, the Solomons, and Vanuatu were close enough to allow for amalgamation of biotas until the late Miocene (ca. $10 \mathrm{Ma}$, as parts of the Melanesian arc); (2) New Guinea was in contact with Fiji, the Solomons, and Vanuatu through the western end of the Melanesian arc (ca. $40 \mathrm{Ma}$ ) and later via the South Caroline arc (until ca. $10 \mathrm{Ma}$ ); and (3) there was a discontinuous land-bridge between New Guinea and the Philippines via the Philippine- 
Halmahera arc from around $25 \mathrm{Ma}$. Thus, there have been numerous opportunities for dispersal both eastward and westward during the Miocene with subsequent radiation, especially in the Philippines, which continued to change until about 10 Mya (Burrett et al., 1991; Hall, 1998). Clear-cut biogeographic patterns cannot, therefore, be expected.

Concluding remarks-By combining the two low-copy nuclear genes $P R K$ and $R P B 2$, we have confirmed that the genera Heterospathe and Rhopaloblaste are distinct and unrelated groups that are both members of the Areceae. Rhopaloblaste is strongly supported as monophyletic, whereas the monotypic genus Alsmithia is clearly nested within Heterospathe, indicating that the taxonomic boundaries of Heterospathe should be altered slightly (Norup, 2005). Relative to the results of the molecular analyses, the morphological characters used in the delimitation of Heterospathe and Rhopaloblaste are homoplasious, especially in Heterospathe, for which no unique characters have been identified (cf. Hughes et al., 2004). Only by applying suites of characters is it possible to firmly establish generic limits, accounting for historical problems with generic delimitation.

Despite recovering many novel relationships, our phylogenies are frustratingly ambiguous in places. A low level of resolution in a large group of plants in the Indo-Pacific ocean, coupled with a lack of morphological synapomorphies, a nonfit between current infrafamilar classifications, and complex biogeographic history (as for Heterospathe and Rhopaloblaste) has also recently been documented within Araliaceae (Plunkett et al., 2004; Wen et al., 2004). The authors concluded that the large polytomies found in a clade consisting of taxa from Malesia, the Indian and Pacific Oceans, and Australia might be a result of a rapid simultaneous radiation early in the evolutionary history of the clade, although taxon and character sampling may also be influential. Whether or not this represents a plausible hypothesis for the poor resolution within the Indo-Pacific pseudomonomerous clade remains to be evaluated.

\section{LITERATURE CITED}

Asmussen, C. B., W. J. Baker, And J. Dransfield. 2000. Phylogeny of the palm family (Arecaceae) based on rpsl6 intron and $\operatorname{trnL}-\operatorname{trn} F$ plastid DNA sequences. In K. L. Wilson and D. A. Morrison [eds.], Monocots: systematics and evolution, 525-537. CSIRO, Melbourne, Australia.

Asmussen, C. B., AND M. W. Chase. 2001. Coding and noncoding plastid DNA in palm systematics. American Journal of Botany 88: 11031117.

Asmussen, C. B., J. Dransfield, V. Deickmann, A. S. Barfod, J.-C. PINTAUD, AND W. J. BAKER. In press. A new subfamily classification of the palm family (Arecaceae): evidence from plastid DNA phylogeny. Botanical Journal of the Linnean Society.

BAKER, W. J. 2002. The palms of New Guinea project. Flora Malesiana Bulletin 13: 35-37.

Baker, W. J., C. B. Asmussen, S. Barrow, J. Dransfield, and T. A. HedDERson. 1999. A phylogenetic study of the palm family (Palmae) based on chloroplast DNA sequences from the trnL-trnF region. Plant Systematics and Evolution 219: 111-126.

Baker, W. J., J. Dransfield, and T. A. Hedderson. 2000a. Phylogeny, character evolution, and a new classification of the calamoid palms. Systematic Botany 25: 297-322.

Baker, W. J., T. A. Hedderson, And J. Dransfield. 2000b. Molecular phylogenetics of subfamiliy Calamoideae (Palmae) based on nrDNA
ITS and cpDNA rps16 intron sequence data. Molecular Phylogenetics and Evolution 14: 195-217.

Baker, W. J., T. A. Hedderson, and J. Dransfield. 2000c. Molecular phylogenetics of Calamus (Palmae) and related rattan genera based on 5S nrDNA spacer sequence data. Molecular Phylogenetics and Evolution 14: 218-231.

BAKer, W. J., AND A. H. B. Loo. 2004. A synopsis of the genus Hydriastele. Kew Bulletin 59: 61-68.

Baker, W. J., S. Zona, C. D. Heatubun, C. E. Lewis, R. A. Maturbongs, AND M. V. NoruP. 2006. Dransfieldia (Arecaceae) - a new palm genus from western New Guinea. Systematic Botany 31: 60-68.

BANKA, R., AND W. BAKER. 2004. A monograph of the genus Rhopaloblaste (Arecaceae). Kew Bulletin 59: 47-60.

BARFoD, A. S. 2000. A new species of Licuala from New Guinea. Palms 44: 198-201.

Barfod, A. S., R. BanKa, And J. L. Dowe. 2001. Field guide to palms in Papua New Guinea. AAU Reports 40: 1-77.

Beccari, O. 1877. Palme Papuane. Malesia 1: 52-53.

BeCCARI, O. 1885. Reliquiae Schefferianae. Illustrazione di alcune palme viventi nel Giardino Botanico di Buitenzorg. Annales du Jardin Botanique de Buitenzorg 2:90, 126

Beccari, O. 1909. Notes on Philippine palms. II. Philippine Journal of Science, Botany 4: 610-637.

Burrett, C., N. Duhig, R. Berry, and R. Varne. 1991. Asian and southwestern Pacific continental terranes derived from Gondwana, and their biogeographic significance. Australian Systematic Botany 4: $13-24$.

Chase, M. W., and H. G. Hills. 1991. Silica gel: an ideal material for field preservation of leaf samples for DNA studies. Taxon 40: 215-220.

Denton, A. L., B. L. McConaughy, and B. J. Hall. 1998. Usefulness of RNA polymerase II coding sequences for estimation of green plant phylogeny. Molecular Biology and Evolution 15: 1082-1085.

Dolphin, K., R. Belshaw, C. D. L. Orme, and D. L. J. Quicke. 2000. Noise and incongruence: interpreting results of the incongruence length difference test. Molecular Phylogenetics and Evolution 17: 401-406.

Dowe, J. L., AND P. CABALION. 1996. A taxonomic account of Arecaceae in Vanuatu, with descriptions of three new species. Australian Systematic Botany 9: 1-60.

Dowe, J. L., AND N. W. Uhl. 1989. Carpoxylon macrospermum. Principes 33: $68-73$.

DoyLE, J. J., AND J. L. DoyLe. 1987. A rapid DNA isolation procedure from small quantities of fresh leaf tissue. Phytochemistry Bulletin 19: 11-15.

Dransfield, J. 1991. Lemurophoenix (Palmae: Arecoideae), a new genus from Madagascar. Kew Bulletin 46: 61-68.

Dransfield, J. 1999. Species and species concepts in Old World palms. In A. Henderson and F. Borchsenius [eds.], Evolution, variation and classification of palms. Memoirs of the New York Botanical Garden, vol. 83, 5-20. New York Botanical Garden Press, Bronx, New York, USA.

Dransfield, J., AND H. J. BeentJe. 1995. The palms of Madagascar. Royal Botanic Gardens Kew and the International Palm Society, Norwich Print Services, Kew, UK.

Dransfield, J., And N. W. Uhl. 1998. Palmae. In K. Kubitzki [ed.], The families and genera of vascular plants, vol. 4, Flowering plants: monocotyledons, 306-389. Springer-Verlag, Berlin, Germany.

Dransfield, J., N. W. Uhl, C. B. Asmussen, W. J. Baker, M. M. Harley, AND C. E. LewIS. 2005. A new phylogenetic classification of the palm family, Arecaceae. Kew Bulletin 60: 559-569.

Essig, F. B., T. J. ManKa, AND L. Bussard. 1999. A systematic histological study of palm fruits. III. Subtribe Iguanurinae (Arecaceae). Brittonia 51: 307-325.

Farris, J. S., M. Källersjö, A. G. Kluge, and C. Bult. 1995. Testing significance of incongruence. Cladistics 10: 315-319.

Felsenstein, J. 1985. Confidence limits on phylogenies: an approach using the bootstrap. Evolution 39: 783-791.

FERnANDO, E. S. 1990a. A preliminary analysis of the palm flora of the Philippine Islands. Principes 34: 28-45.

Fernando, E. S. 1990b. The genus Heterospathe (Palmae, Arecoideae) in the Philippines. Kew Bulletin 45: 219-234. 
FiтcH, W. M. 1971. Towards defining the course of evolution: minimum change for a specific tree typology. Systematic Zoology 20: 406-416.

GovaERTS, R., AND J. DRANSFIELD. 2005. World checklist of palms. Royal Botanic Gardens, Kew, UK.

GunN, B. F. 2004. The phylogeny of the Cocoeae (Arecaceae) with emphasis on Cocos nucifera. Annals of Missouri Botanical Gardens 91: 505-522.

HAHN, W. J. 2002. A phylogenetic analysis of the arecoid line of palms based on plastid DNA sequence data. Molecular Phylogenetics and Evolution 23: 189-204.

HaLl, R. 1998. The plate tectonics of Cenozoic SE Asia and the distribution of land and sea. In R. Hall and J. D. Holloway [eds.], Biogeography and geological evolution of SE Asia, 99-131. Backhuys Publishers, Leiden, Netherlands.

HookeR, J. D. 1883. Ordo 187. Palmae. In G. Bentham and J. D. Hooker [eds.], Genera plantarum 3, 870-948. Lovell Reeve, London, UK.

Huelsenbeck, J. P., J. J. Bull, and C. W. Cunningham. 1996. Combining data in phylogenetic analysis. Trends in Ecology and Evolution 4: $152-158$.

Hughes, C. E., G. P. Lewis, A. D. Yomona, and C. Reynel. 2004. Maraniona. A new dalbergioid legume genus (Leguminosae, Papilionoideae) from Peru. Systematic Botany 29: 366-374.

JACKSON, B. D. 1895. Index kewensis, vol. 2, part 4. Clarendon Press, Oxford, UK.

Kawagishi, M., M. Yamagishi, and A. Ishihama. 1993. Cloning and sequence determination of the Schizosaccharomyces pombe rpb2 gene encoding the subunit 2 of RNA polymerase II. Nucleic Acids Research 21: 469-473.

Kelchner, S. A. 2000. The evolution of non-coding chloroplast DNA and its application in plant systematics. Annals of Missouri Botanical Garden 87: 482-498.

Lewis, C. E., AND J. J. Doyle. 2001. Phylogenetic utility of the nuclear gene malate synthase in the palm family (Arecaceae). Molecular Phylogenetics and Evolution 19: 409-420.

Lewis, C. E., AND J. J. Doyle. 2002. Phylogenetics of tribe Areceae (Arecaceae) using low-copy nuclear genes. Plant Systematics and Evolution 236: 1-17.

Lewis, C. E., And N. MartinÉz. 2000. Identity of the Hyophorbe palms at the Botanical Garden of Cienfuegos, Cuba. Palms 44: 93-97.

Loo, A. H. B., J. Dransfield, M. W. Chase, and W. J. Baker. 2006. Low copy nuclear DNA, phylogeny and the evolution of dichogamy in the betel nut palms and their relatives (Arecinae; Arecaceae). Molecular Phylogenetics and Evolution: in press.

Maddison, D. R., AND W. P. Maddison. 2003. MacClade, version 4.06. Analysis of phylogeny and character evolution. Sinauer, Sunderland, Massachusets, USA.

Martelli, U. 1934. Generi, specie, e varietá nuove di palme gerontogee della tribu Arecaceae lasciate inedite dal Dr. Od. Beccari ed ordinate acura di U. Martelli. Atti Società Toscana di Scienze Naturali residente in Pisa. Memorie 44: 114-176.

Martelli, U. 1935. La sinonimia delle palme gerontogee della tribu delle Areceae. Nuovo Giornale Botanico Italiano, Nouva Serie 42: 81.

Moore, H. E. JR. 1970. The genus Rhopaloblaste (Palmae). Principes 14: 75-92.

Moore, H. E. JR., R. H. Phillips, and S. Vodonaivalu. 1982. Additions to the palms of Fiji. Principes 26: 122-125.

Morley, R. J. 2000. Origin and evolution of tropical rain forest. Wiley, Chichester, UK.

Morley, R. J. 2001. Tertiary history of the Malesian flora: a palynological perspective. In L. G. Saw, L. S. L. Chua, and K. C. Khoo [eds.], Taxonomy: the cornerstone of biodiversity, 197-210. Proceeding of the Fourth International Flora Malesiana Symposium 1998, The Research Institute Malaysia, Kepong, Kuala Lumpur.

Mort, M. E., AND D. J. CRAWFord. 2004. The continuing search: low-copy nuclear sequences for lower-level plant molecular phylogenetic studies. Taxon 53: 257-261.

Moylan, E. C., J. R. Bennet, M. A. Carine, R. G. Olmstead, and R. W. ScotLAND. 2004. Phylogenetic relationships among Strobilanthes s. 1.
(Acanthaceae): evidence from ITS nrDNA, trnL-F, cpDNA, and morphology. American Journal of Botany 91: 724-735.

Norup, M. V. 2005. Alsmithia subsumed in Heterospathe (Arecaceae, Arecoideae). Novon 15: 455-457.

Norup, M. V., W. Baker, C. Lewis, A. Loo, and J. Dransfield. 2003. Phylogenetic and biogeographical studies of the Indo-Pacific clade of tribe Areceae (Palmae), based on two low-copy nuclear genes. Monocots III symposium, 2003, Ontario, California, USA. Rancho Santa Ana Botanical Gardens, California, USA (Abstract).

OXELMAN, B., AND B. BREMER. 2000. Discovery of paralogous nuclear gene sequences coding for the second-largest subunit of RNA polymerase II (RPB2) and their phylogenetic utility in Gentianales of the asterids. Molecular Biology and Evolution 17: 1130-1145.

Oxelman, B., N. Yoshikawa, B. L. McConaughy, J. Luo, A. L. Denton, AND B. D. Hall. 2004. Rpb2 gene phylogeny in flowering plants, with particular emphasis on asterids. Molecular Phylogenetics and Evolution 32: 462-479.

Pfeil, B. E., C. L. Brubaker, L. A. Craven, and M. D. Crisp. 2004. Paralogy and orthology in the Malvaceae $r p b 2$ gene family: investigation of gene duplication in Hibiscus. Molecular Biology and Evolution 21: 1428-143.

Pintaud, J.-C., And D. R. Hodel. 1998. The palms of New Caledonia. Allen Press, Lawrence, Kansas, USA.

Plunkett, G. M., J. Wen, and P. P. Lowry II. 2004. Infrafamilial classifications and characters in Araliaceae: insights from the phylogenetic analysis of nuclear (ITS) and plastid $(\operatorname{trn} L-\operatorname{trn} F)$ sequence data. Plant Systematics and Evolution 245: 1-39.

Popp, M., AND B. Oxelman. 2004. Evolution of a RNA polymerase gene family in Silene (Caryophyllaceae)—incomplete concerted evolution and topological congruence among paralogues. Systematic Biology 53: 914-932

Reeves, G., M. W. Chase, P. Goldblatt, P. Rudall, M. W. Fay, A. V. Cox, B. LeJeune, AND T. Souza-ChiEs. 2001. Molecular systematics of Iridaceae: evidence from four plastid DNA regions. American Journal of Botany 88: 2074-2087.

Ridder-Numan, J. W. A. 1996. Historical biogeography of the Southeast Asian genus Spatholobus (Legum.-Papilionoideae) and its allies. Blumea Supplement 10: 1-144.

Roncal, J., J. Francisco-Ortega, C. B. Asmussen, and C. E. Lewis. 2005. Molecular phylogenetics of tribe Geonomeae (Arecaceae) using nuclear DNA sequences of phosphoribulokinase and RNA polymerase II. Systematic Botany 30: 275-283.

Salamin, N., M. W Chase, T. R. Hodkinson, and V. Savolainen. 2003. Assessing internal support with large phylogenetic DNA matrices. Molecular Phylogenetics and Evolution 27: 528-539.

SCHeFfer, R. H. C. C. 1876. Sur quelques palmiers du groupe des Arécinées. Deuxieme parte. Annales du Jardin Botanique de Buitenzorg 1: 103-164.

Sheahan, M. C., and M. W. Chase. 2000. Phylogenetic relationships within Zygophyllaceae based on DNA sequences of three plastid regions, with special emphasis on Zygophylloideae. Systematic Botany 25: 371-384.

Small, R. L., R. C. Cronn, and J. F. Wendel. 2004. Use of nuclear genes for phylogeny reconstruction in plants. Australian Systematic Botany 17: $145-170$.

Stauffer, F. W., W. J. Baker, J. Dransfield, and P. K. Endress. 2004. Comparative floral structure and systematics of Pelagodoxa and Sommieria (Arecaceae). Botanical Journal of the Linnean Society 146: $27-39$.

SWOFFORD, D. L. 2002. PAUP*: phylogenetic analysis using parsimony (*and other methods), version 4. Sinauer, Sunderland, Massachusetts, USA.

Tam, S.-M., P. C. Boyce, T. M. Upson, D. Barabé, A. Bruneau, F. Forest, AND J. S. PARKER. 2004. Intergeneric and infrafamilial phylogeny of subfamily Monsteroideae (Araceae) revealed by chloroplast trnL-F sequences. American Journal of Botany 91: 490-498.

Thomas, M. M., N. C. Garwood, W. J. Baker, S. A. Henderson, S. J. Russell, D. R. Hodel, and R. M. Bateman. 2006. Molecular phylogeny of the palm genus Chamaedorea, based on the low-copy 
nuclear genes PRK and RPB2. Molecular Phylogenetics and Evolution.

Turner, H. 1995. Cladistic and biogeographic analyses of Arytera Blume and Mischarytera gen. nov. (Sapindaceae). Blumea Supplement 9: 1230.

UhL, N. W., AND J. Dransfield. 1987. Genera palmarum: a classification of palms based on the work of H. E. Moore Jr. International Palm Society and L. H. Bailey Hortorium. Allen Press, Lawrence, Kansas, USA.

Wen, J., C. Lee, G. Plunkett, and P. P. Lowry, II. 2004. Evolution of Araliaceae in Asia: inference from the ITS, $n d h F, \operatorname{trn} L-F$, and molecular data. Sixth International Flora Malesiana Symposium,
2004, Los Baños, Philippines. University of the Philippines, Los Baños, Philippines (Abstract).

WIENS, J. J. 1998. Combining data sets with different phylogenetic histories. Systematic Biology 47: 568-581.

Wilson, M. A., B. Gaut, AND M. T. ClegG. 1990. Chloroplast DNA evolve slowly in the palm family (Arecaceae). Molecular Biology and Evolution 7: 303-314.

Yoder, A. D., J. A. Irwin, AND B. A. PAyseur. 2001. Failure of the ILD to determine data combinability for slow loris phylogeny. Systematic Biology 50: 408-424

Zona, S. 2003. Endosperm condition and the paradox of Ptychococcus paradoxus. Telopea 10: 1-7.

APPENDIX. Taxa used in this study, voucher information, GenBank accession numbers for the two regions studied. A dash indicates the region was not sampled. Herbarium acronyms are given in parentheses after accessions: AAU = University of Aarhus, BH $=$ Cornell University, New York, BISH $=$ Bishop Museum, Hawaii, FTG = Fairchild Tropical Botanic Garden, Miami, GUAM = University of Guam, JCT = James Cook University of Northern Queensland, K = Royal Botanic Gardens, Kew, LAE = Papua New Guinea Forest Research Institute, LBC = University of the Philippines at Los Baños, MAK = Tokyo Metropolitan University, NOU = Institut de Recherche pour le Développement, New Caledonia, NY = New York Botanical Garden, $\mathrm{P}=$ Muséum National d'Histoire Naturelle, Paris, SUVA = University of the South Pacific, Fiji, TL = Université Paul Sabatier, Toulouse, VEN = Fundación Instituto Botánico de Venezuela Dr. Tobías Lasser. Asterisks indicate sequences that were cloned. In the case of several clones per species, underlining indicates the clone used in the final matrix. Sequences published previously by Lewis and Doyle (2002) have GenBank numbers starting with AF.

Subfamily; Tribe; Subtribe

Taxon-Voucher specimen (Herbarium); GenBank accession: PRK, RPB2.

Arecoideae; Areceae; Archontophoenicinae

Actinorhytis calapparia (Blume) H. Wendl. \& Drude ex Scheff.Heatubun 192 (K); AJ831223, AJ830025. Actinokentia huerlimannii (Brongn.) Dammer-Pintaud 465 (NOU); AJ831222, AJ830023. Archontophoenix purpurea Hodel \& Dowe-Pintaud 492 (TL); AJ831227, AJ830028. Chambeyronia macrocarpa (Brongn.) Vieill. ex Becc.-Pintaud 512 (P); AJ831260, AJ830056. Kentiopsis oliviformis (Brongn. \& Gris.) Brongn._Pintaud 358 (K); AF453353, AY543100.

Arecoideae; Areceae; Arecinae

Areca catechu L.-Lewis 98-093 (BH) for PRK, TCMK 21 (K) for RPB2; AF453333, AY543109. Nenga pumila (Blume) H. Wendl.) var. pachystachya (Blume) Fernando-Baker 994 (FTG); AY348914, AY543154. Pinanga coronata (Blume ex Mart.) Blume-Baker 1145 (K); AY348944, AY543156.

Arecoideae; Areceae; Basseliniinae

Alloschmidia glabrata (Becc.) H.E. Moore-Pintaud 468 (K); AJ831225, AJ830026. Basselinia velutina Becc.-Pintaud 553 (P); AJ831233, AJ830031. Burretiokentia vieillardii (Brongn. \& Gris.) Pic.Serm.Pintaud 197 (NY); AJ831243, AJ830039. Campecarpus fulcitus (Brongn.) H. Wendl. ex Becc._Pintaud 524 (P); AJ831258, AJ830054. Cyphophoenix nucele H.E. Moore-Pintaud 372 (K); AJ831266, AJ830061. Cyphosperma balansae (Brongn.) H. Wendl. ex Salomon-Baker 89-030 (BISH); AF453340, AY543098. Physokentia petiolata (Burret) D. Fuller-Pintaud 452 (TL); AJ831322, AJ830138. Veillonia alba H.E. Moore-Pintaud 277 (K); AJ831336*, AJ831337*, AJ831338*, AJ831339*, AJ831340*, AJ831341*, AJ 830149 .

Arecoideae; Areceae; Carpoxylinae

Carpoxylon macrospermum H. Wendl. \& Drude-Zona 722 (FTG); AF453337, AJ830055. Neoveitchia storckii (H. Wendl.) Becc.Roncal 73 (FTG); AJ831319, AJ830130. Satakentia liukiuensis (Hatus.) H.E. Moore-Lewis 99-051 (BISH); AF453376, AJ830146.

Arecoideae; Areceae; Clinospermatinae

Brongniartikentia lanuginosa H.E. Moore-Pintaud 368 (P); AJ831236*, AJ831237*, AJ831238*, AJ831239*, AJ831240*, AJ830033. Clinosperma bracteale (Brongn.) Becc.-Pintaud 349 (K); AJ831261, AJ830057. Cyphokentia macrostachya Brongn.Pintaud 558 (P); AJ831264, AJ830060*. Lavoixia macrocarpa H.E. Moore-Pintaud 364 (P); AJ831302, AJ830110. Moratia cerifera $\mathrm{H}$. E. Moore—Pintaud 347 (K); AJ831318, AJ830129.

Arecoideae; Areceae; Dypsidinae
Dypsis lutescens (H. Wendl.) Beentje \& J. Dransf.-Lewis 00-004 (BH); AF453346, AJ830078. Lemurophoenix halleuxii J. Dransf.-Lewis 98-073 (BH); AF453354, AM260636. Marojejya darianii J. Dransf. \& N.W. Uhl-Lewis 99-037 (BISH); AF453359, AJ830121*. Masoala madagascariensis Jum.-1992-3552 (K); AF453360, AJ830128.

Arecoideae; Areceae; Linospadicinae

Calyptrocalyx hollrungii (Becc.) Dowe \& M.D. Ferrero-Baker 1176 (K); AJ831251 AJ830043. Howea belmoreana (C. Moore \& F. Muell.) Becc.-Baker 1154 (K); AJ831294, AJ830098. Laccospadix australasicus H. Wendl. \& Drude-Baker 1172 (K); AJ831300, AJ830108. Linospadix albertisiana (Becc.) Burret-Dowe 720 (JCT); AJ831305, AJ830119.

Arecoideae; Areceae; Oncospermatinae

Acanthophoenix rubra (Bory) H. Wendl._Lewis 98-067 (BH); AF453329, AJ830020. Deckenia nobilis H. Wendl. ex Seem.Lewis 98-031 (BH); AF453342, AJ830063. Oncosperma tigillarium (Jack) Ridl._Lewis 98-051 (BH); AF453364, AJ830134. Tectiphiala ferox H.E. Moore-Lewis 98-070 (BH); AF453380, AJ830148.

Arecoideae; Areceae; Ptychospermatinae

Adonidia merrillii (Becc.) Becc.-Zona 874 (FTG); AJ831224, AJ830193. Balaka longirostris Becc._Pintaud 463 (SUVA); AJ831229, AJ830029. Brassiophoenix drymophloeoides BurretCoons 1398 (FTG); AJ831235, AJ830195. Carpentaria acuminata (H. Wendl. \& Drude) Becc.-Zona 827 (FTG); AJ831259, AJ830196. Drymophloeus litigiosus (Becc.) H.E. Moore-Barrow 125 (K); AJ831267, AJ830197. Normanbya normanbyi (F.Muell.) L.H. Bailey-Lewis 98-091 (BH); AF453363, AJ830132. Ponapea palauensis Kaneh-Lewis 99-055 (BISH); AJ831328, AJ830203. Ptychococcus paradoxus (Scheff.) Becc.-Baker 572 (K); AJ831324, AJ830200. Ptychosperma salomonense Burret-Houghton 1300 (FTG); AF453371, AY543105. Solfia samoensis Rech.-Tipama'a 001 (FTG); AJ831334, AJ830204. Veitchia spiralis H. Wendl.-Zona 724 (FTG); AJ831342, AJ830205. Wodyetia bifurcata A.K. IrvineZona 906 (FTG); AJ831343, AJ830206.

Arecoideae; Areceae; Rhopalostylidinae

Hedyscepe canterburyana (C. Moore \& F. Muell.) H. Wendl. \& DrudePintaud 407 (TL); AJ831276, AJ830081. Rhopalostylis baueri (Hook. f. ex Lem.) H. Wendl. \& Drude-Pintaud 384 (NY); AJ831333, AJ830145.

Arecoideae; Areceae; Verschaffeltiinae

Nephrosperma vanhoutteanum (H. Wendl. ex Van Houtt.) Balf. f.Lewis 98-006 (BH); AF453362, AJ830131. Phoenicophorium 
borsigianum (K. Koch) Stuntz-Lewis 98-024 (K); AF453368, AJ830136. Roscheria melanochaetes (H. Wendl.) H. Wendl. ex Balf. f.—Lewis 98-036 (BH); AF453374, AJ830140*. Verschaffeltia splendida $\mathrm{H}$. Wendl.—Lewis 98-039 (BH); AF453381, AJ830150.

Arecoideae; Areceae; unplaced

Alsmithia longipes H.E. Moore-Baker 1180 (FTG); AJ831226, AJ830027. A. longipes H.E. Moore-Zona 1039 (FTG); AM260638, AM260637. Bentinckia condapanna Berry ex Roxb.-1993-2989 (K); AF453336, AJ830032. Clinostigma savoryanum (Rehder \& E.H. Wilson) H.E. Moore \& Fosberg—Pintaud 442 (MAK); AJ831263, AJ830059. Cyrtostachys renda Blume-1982-5882 (K); AF453341, AJ830062. Dictyosperma album (Bory) Scheff.-Lewis 98-031 (BH); AF453343, AJ830064. Heterospathe cagayanensis Becc.-Kyburz s. n. (no voucher); AJ831277, AJ830082. H. delicatula H.E. MooreBaker 1190 (K); AJ831278, AJ830083. H. elata Scheff.-Chapin 55 (K); AJ831279, AJ830084. H. elata Scheff.-Houghton \& Hubbuch 1024 (FTG); AJ831292, AJ830096. H. elata Scheff.-Lewis 99-034 (GUAM); AF453350, AJ830085. H. humilis Becc.—Banka 2011 (K); AJ831280, AJ830086. H. macgregorii (Becc.) H. E. Moore-Baker 651 (K); AJ831281, AJ830087. H. philippinensis (Becc.) Becc.Fernando 1623 (LBC); AJ831282, AJ833634. H. phillipsii D. Fuller \& Dowe-Pintaud 454 (SUVA); AJ831283, AJ830088*. H. scitula Fernando-Fernando 1625 (LBC); AJ831284, AJ830089. $\boldsymbol{H}$. sibuyanensis Becc.-Zona 1050 (FTG); AJ831285, AJ830090. $\boldsymbol{H}$. sp.-Baker 1115 (K); AJ831286, AJ830091. H. sp.—Baker 1130 (K); AJ831290, - . H. sp.-Baker 1142 (K); AJ831288, AJ830093. $\boldsymbol{H}$. sp.-Banka 2008 (K); AJ831289, AJ830094. H. sp. nov.-Fernando 1624 (LBC); AJ831291, AJ830095. Hydriastele beguinii (Burret) W. J. Baker \& Loo-Zona 799 (FTG); AY348951, AY543163. H. brassii (Burret) W.J. Baker \& Loo-Baker 823 (K); AY348916, AY543116. H. costata F.M. Bailey-Baker 836 (K); AY348925, AY543127. H. microspadix (Warb. ex K. Schum. \& Lauterb.) Burret-Baker 573 (K); AY348932, AY543136. Iguanura wallichiana (Mart.) Becc.Lewis 99-049 (BISH); AF453352, AY543099. Lepidorrhachis mooreana (F. Muell.) O.F. Cook-Baker 1168 (K); AJ831304, AJ830118. Loxococcus rupicola (Thwaites) H. Wendl. \& Drude-
1990-2497 (K); AY348942, AY543151. Ptychosperma micranthum Becc.—Baker 1066 (K); AJ831326, AJ830139. Rhopaloblaste augusta (Kurz) H.E. Moore-Lewis 99-004 (FTG); AF453373, AY543107. R. ceramica (Miq.) Burret-Banka 2050 (LAE); AJ831329, AJ830141. R. ledermanniana Becc.-Heatubun 191 (K); AJ831331, AJ830144. R. ledermanniana Becc.-Maturbongs 650 (K); AJ831332, AJ830143. R. singaporensis (Becc.) Hook. f.-Baker 1174 (K); AJ831330, AJ830142.

Arecoideae; Euterpeae

Neonicholsonia watsonii Dammer-Lewis 99-052 (BISH); AJ831356; AJ830172.

Arecoideae; Geonomateae

Asterogyne martiana (H. Wendl.) H. Wendl. ex Drude-Baker 89021 (BISH); AF453334, AJ830154. Calyptrogyne costatifrons (L.H. Bailey) Nevers-Knudsen \& Asmussen 603 (AAU); AJ831347, AJ830208. Geonoma deversa (Poit.) Kunth-Roncal 19 (FTG); AJ831354, AJ830210. Pholidostachys pulchra H. Wendl. ex Burret-Roncal 26 (FTG); AJ831360, AJ830211.

Arecoideae; Iriarteeae

Socratea exorrhiza (Mart.) H. Wendl.-Baker 992 (FTG); AF453378, AY543108.

Arecoideae; Leopoldinieae

Leopoldinia pulchra Mart.-Romero 3060 (VEN); AF453355, AY543102.

Arecoideae; Manicarieae

Manicaria saccifera Gaertn.-Henderson s.n. (NY); AF453358, AJ830173.

Arecoideae; Pelagodoxeae

Pelagodoxa henryana Becc.-1988-2933 (K); AJ831321, AJ830135. Sommieria leucophylla Becc.-1992-3571 (K); AJ831335, AJ830147.

Arecoideae; Podococceae

Podococcus barteri G. Mann \& H. Wendl.-Reitsma 2840 (BH); AF453370, AJ830180.

Coryphoideae; Livistoneae

Chamaerops humilis L.—Lewis 99-012 (BH); AF453339, AY543097. 